\title{
Epidemiology of diabetic retinopathy, diabetic macular edema and related vision loss
}

\author{
Ryan Lee ${ }^{1,2}$, Tien Y. Wong ${ }^{1,2,3}$ and Charumathi Sabanayagam ${ }^{1,2,3^{*}}$
}

\begin{abstract}
Diabetic retinopathy (DR) is a leading cause of vision-loss globally. Of an estimated 285 million people with diabetes mellitus worldwide, approximately one third have signs of DR and of these, a further one third of DR is vision-threatening DR, including diabetic macular edema (DME). The identification of established modifiable risk factors for DR such as hyperglycemia and hypertension has provided the basis for risk factor control in preventing onset and progression of DR. Additional research investigating novel risk factors has improved our understanding of multiple biological pathways involved in the pathogenesis of DR and DME, especially those involved in inflammation and oxidative stress. Variations in DR prevalence between populations have also sparked interest in genetic studies to identify loci associated with disease susceptibility. In this review, major trends in the prevalence, incidence, progression and regression of DR and DME are explored, and gaps in literature identified. Established and novel risk factors are also extensively reviewed with a focus on landmark studies and updates from the recent literature.
\end{abstract}

Keywords: Diabetic retinopathy, Diabetic macular edema, Epidemiology, Risk factors

\section{Introduction}

Diabetic Retinopathy (DR) is the leading cause of vision loss in adults aged 20-74 years [1]. From 1990-2010, DR ranked as the fifth most common cause of preventable blindness and fifth most common cause of moderate to severe visual impairment [2]. In 2010, of an estimated 285 million people worldwide with diabetes, over one-third have signs of DR, and a third of these are afflicted with vision-threatening diabetic retinopathy (VTDR), defined as severe non-proliferative DR or proliferative DR (PDR) or the presence of diabetic macular edema (DME) [3]. These estimates are expected to rise further due to the increasing prevalence of diabetes, ageing of the population and increasing of life expectancy of those with diabetes.

PDR is the most common vision-threatening lesion particularly among patients with type 1 diabetes. However, DME is responsible for most of the visual loss experienced by patients with diabetes as it remains the major cause of

\footnotetext{
* Correspondence: charumathi.sabanayagam@seri.com.sg

'Singapore Eye Research Institute, Singapore National Eye Centre, Singapore, Singapore

${ }^{2}$ Yong Loo Lin School of Medicine, National University of Singapore, Singapore, Singapore

Full list of author information is available at the end of the article
}

vision loss in the highly prevalent type 2 diabetes [4] and is invariably present in patients with type 2 diabetes with PDR [5]. In addition to vision loss, DR and DME have also been shown to contribute to the development of other diabetes-related complications including nephropathy, peripheral neuropathy and cardiovascular events [6-9].

The most clinically important risk factors for progression to vision loss include duration of diabetes, hyperglycemia and hypertension. Control of serum glucose and blood pressure have been shown to be effective in preventing vision loss due to DR. Prevalence and risk factors of DR have been studied widely in previous studies including regional and ethnic differences, but epidemiological data on DME are relatively scarce. A review conducted in 2012 suggested that up to $7 \%$ of people with diabetes may have DME and risk factors of DME are largely similar to DR. Recently, new information on the epidemiology of DR and DME has been published from both developed and developing countries. In this review, we summarize the prevalence of DR and highlight regional differences in the epidemiology of DR from recent studies. We also review the incidence, progression and regression of DR and DME, as well as factors contributing to the progression or regression of DR and DME. 


\section{Review}

Prevalence of DR

A pooled individual participant meta-analysis involving 35 studies conducted worldwide from 1980 to 2008, estimated global prevalence of any DR and PDR among patients with diabetes to be 35.4 and $7.5 \%$ respectively [3]. Prevalence of any DR and PDR was higher in those with type 1 diabetes, compared to those with type 2 diabetes (77.3 vs. $25.2 \%$ for any DR, 32.4 vs. $3.0 \%$ for PDR). Table 1 summarizes the findings of various prevalence studies, organized by region, in comparison to the global estimate. Estimates on DR prevalence in type 1 diabetes in Europe and the USA range between 36.5-93.6 \%, with VTDR prevalence estimated between 6.7-34.9 \% [10-16]. The wide range of prevalence observed may be due to differences in healthcare systems and socioeconomic factors between the studied populations, but conclusions cannot be made as key characteristics such as known duration of diabetes vary greatly between the sampled populations. In the East (Asia and the Middle East), prevalence studies focused on DR in type 2 diabetes alone, due to the low prevalence of type 1 diabetes in these populations. Hence, comparison of DR prevalence between the East and West is restricted only to type 2 diabetes.

In general, patients with type 2 diabetes in Western communities have a higher prevalence of DR than their Asian counterparts. In the USA, studies estimate that $28.5-40.3 \%$ of patients with type 2 diabetes had DR, and $4.4-8.2 \%$ of them had VTDR $[17,18]$. In contrast, most Asian countries report DR prevalence to be between 12.1-23.0 \%, and VTDR prevalence to be between $4.3-4.6 \%$ [19-22].

Singapore is a notable exception to this trend. Despite being an Asian country, paralleling the rapid urbanization, industrialization and internal migration that took place over the past five decades in Singapore, DR prevalence in Singapore is reported to be higher $(33.9 \%)$ than other Asian countries but comparable to that seen in the Western world [23]. Within the three major ethnic groups in Singapore, the Malays and Indians were reported to have higher a prevalence of DR (33.4 \% in Malays, $33.0 \%$ in Indians) compared to the Chinese (25.4\%) [23]. In addition to ethnic differences, a study conducted in Singapore also highlighted geographic heterogeneity in the prevalence of DR within ethnic Indian groups living in Singapore (30.4 \%) [24] and in urban India (18 \%) [21, 25]. It has been speculated that increased acculturation to a westernized lifestyle associated with increased prevalence of obesity and diabetes, and increased awareness among Indians living in Singapore has led to a higher prevalence, while selective mortality of those with DR in the urban Indian cohorts led to a lower prevalence. In the MiddleEast, Saudi Arabia [26] and Iran [27] both report prevalence that are similar to Western communities (36.8 and
$29.6 \%$, respectively). Of concern is that a large proportion of diagnosed DR is vision threatening, with VTDR prevalence estimated to be higher (10.6-17.5\%) than that observed in the Western world. These observations imply that most of these cases of DR have been detected late, when it has already progressed to a vision-threatening stage, or that these populations are particularly susceptible to severe DR due to ethnic predisposition. Other developed Asian countries such as Hong Kong [19] and South Korea [20] report DR prevalence that is much lower than the global average (12.1 and $15.8 \%$, respectively).

Apart from the east-west divide, rapidly developing economies in Asia such as China and India are observing urban-rural divides in terms of DR disease burden. In China, prevalence of DR was reported to be higher among adults with type 2 diabetes living in rural regions (29.1$43.1 \%$ ) [22, 28], compared to their urban counterparts (18.1 \%) [22]. Conversely, in a study conducted in Chennai, India, DR prevalence was reported to be higher in urban (18.0 \%) [21] compared to rural areas (10.8 \%) [29], possibly due to the increasing affluence accompanied by changes in diet in the urban regions and selective mortality of those with diabetes-related complications in rural regions because of poor access to healthcare. The reason why this urban-rural relationship is reversed in China may represent a case of ethnic predisposition, but this is an area that requires further study. In the past two years, reports on DR prevalence from many developing countries in Asia and Africa have been published [30-35]. Prevalence of DR in Sri Lanka, Bangladesh, Nepal, Tunisia, Kenya and Ethiopia ranged from 21.6-41.4\%. While the sample sizes of these studies tend to be smaller, they still provide insight into the burden of DR in these communities.

Although duration of diabetes is a major risk factor for DR, a few studies reported DR prevalence in newly diagnosed diabetes. Prevalence found in these studies ranged from 2.8 \% in South Korea to 28.6 \% in Singapore [20, 27, 32, 36-39]. Surprisingly, a large percentage $(19.2 \%)$ of newly diagnosed patients with diabetes have DR in Scotland, UK, where there is universal healthcare. This prevalence is even higher than in Nepal (13.0 \%) [32], where access to healthcare is presumably more limited. However, the prevalence of advanced stages of DR or DME was found to be lower among those with newly diagnosed diabetes suggesting diagnosis of DR early in the course of the disease [40].

\section{Incidence of DR}

There are few population-based cohort studies, outside of the USA or UK, which have investigated DR incidence. Various cohort studies investigating DR incidence over the past two decades are listed in Table 2. Comparisons between the East and West, urban and rural populations, 
Table 1 Prevalence of diabetic retinopathy among diabetic subjects

\begin{tabular}{|c|c|c|c|c|c|c|}
\hline Author (Year) & Type of study & Location & $\begin{array}{l}\text { Sample size, } \\
\text { Age in years }\end{array}$ & Diabetes type & Prevalence of DR (\%) & Prevalence of VTDR (\%) \\
\hline \multirow[t]{3}{*}{ Yau (2012) [3] } & \multirow[t]{3}{*}{ Meta-analysis } & \multirow[t]{3}{*}{ Global } & 12,620 & Overall & 35.36 & 11.72 (PDR and/or DME) \\
\hline & & & Mean 58.1 & Type 1 & 77.31 & 38.48 (PDR and/or DME) \\
\hline & & & Range 3-97 & Type 2 & 25.16 & 6.92 (PDR and/or DME) \\
\hline \multicolumn{7}{|l|}{ Asia } \\
\hline \multirow[t]{2}{*}{ Liu (2012) [22] } & \multirow[t]{2}{*}{ Meta-analysis } & \multirow[t]{2}{*}{ China } & 11,996 & \multirow[t]{2}{*}{ Unspecified } & \multirow[t]{2}{*}{23.0} & \multirow[t]{2}{*}{2.8 (PDR) } \\
\hline & & & Range 15-87 & & & \\
\hline \multirow[t]{2}{*}{ Kung (2014) [19] } & \multirow[t]{2}{*}{ Hospital } & \multirow[t]{2}{*}{ Hong Kong } & 15,856 & \multirow[t]{2}{*}{ Type 2} & \multirow[t]{2}{*}{12.1} & \multirow[t]{2}{*}{0.3 (PDR) } \\
\hline & & & Range $\geq 20$ & & & \\
\hline \multirow[t]{2}{*}{ Jee (2013) [202] } & \multirow[t]{2}{*}{ Population } & \multirow[t]{2}{*}{ South Korea } & 1678 & \multirow[t]{2}{*}{ Type 2} & \multirow[t]{2}{*}{15.8} & \multirow[t]{2}{*}{4.6} \\
\hline & & & Mean $58.0 \pm 11.6$ & & & \\
\hline \multirow[t]{3}{*}{ Wong (2008) [39] } & \multirow[t]{3}{*}{ Population } & Singapore & 757 & Type 2 & 35.0 & 9.0 \\
\hline & & & Mean $58.7 \pm 11.0$ & & & \\
\hline & & & Range 40-80 & & & \\
\hline Chiang (2011) [203] & Population & Singapore & 401 & Type 2 & 25.4 & Not investigated \\
\hline & & & Mean $53.0 \pm 9.0$ & & & \\
\hline & & & Range 40-95 & & & \\
\hline Zheng (2012) [204] & Population & Singapore & 1295 & Type 2 & 30.4 & 7.1 \\
\hline & & & Range $\geq 40$ & & & \\
\hline Raman (2009) [21] & Population & India & 1,414 & Unspecified & 18.0 & 4.3 \\
\hline & & & Mean $56.1 \pm 10.1$ & & & \\
\hline & & & Range $\geq 40$ & & & \\
\hline Katulanda (2014) [205] & Hospital & Sri Lanka & 536 & Unspecified & 27.4 & Not investigated \\
\hline & & & Mean $56.4 \pm 10.9$ & & & \\
\hline & & & Range $\geq 18$ & & & \\
\hline Akhter (2013) [31] & Population & Bangladesh & 60 & Unspecified & 21.6 & Not investigated \\
\hline & & & Mean $46.0 \pm 12$ & & & \\
\hline Thapa (2014) [32] & Hospital & Nepal & 277 & Unspecified & 38.26 & 14.44 \\
\hline & & & Mean $62.3 \pm 13.3$ & & & \\
\hline & & & Range $\geq 20$ & & & \\
\hline Middle East & & & & & & \\
\hline Al-Rubeaan (2015) [64] & Population & Saudi Arabia & 50,464 & Type 2 & 19.7 & 10.6 (PDR) 5.7 (DME) \\
\hline & (Reg & & Mean $59.7 \pm 12.8$ & & & \\
\hline & & & Range $\geq 25$ & & & \\
\hline Al Ghamdi (2012) [26] & Population & Saudi Arabia & 612 & Unspecified & 36.8 & 17.5 (Scottish DR \\
\hline & & & Mean 63.3 & & & IVLZ) \\
\hline & & & Range $\geq 50$ & & & \\
\hline Papakonstantinou & Population & Iran & 529 & Type 2 & 29.6 & 11.1 \\
\hline & & & Range 40-80 & & & \\
\hline Europe & & & & & & \\
\hline Thomas (2015) [10] & Population & United Kingdom & 91,393 & Overall & 32.4 & 3.4 (PDR and/or DME) \\
\hline & & & Mean $36.5 \pm 16.4$ & Type 1 & 56.0 & 11.2 (PDR and/or DME) \\
\hline & & & Mean $65.3 \pm 11.7$ & Type 2 & 30.3 & 2.9 (PDR and/or DME) \\
\hline
\end{tabular}


Table 1 Prevalence of diabetic retinopathy among diabetic subjects (Continued)

\begin{tabular}{|c|c|c|c|c|c|c|}
\hline \multirow[t]{2}{*}{ Pugliese (2012) [65] } & \multirow[t]{2}{*}{ Hospital } & \multirow[t]{2}{*}{ Italy } & 15,773 & \multirow[t]{2}{*}{ Type 2} & \multirow[t]{2}{*}{22.2} & \multirow[t]{2}{*}{9.8} \\
\hline & & & Range 59-75 & & & \\
\hline \multirow[t]{3}{*}{ Pedro (2010) [11] } & \multirow[t]{3}{*}{ Population } & \multirow[t]{3}{*}{ Spain } & 8675 & Overall & 26.7 & 0.59 (PDR) \\
\hline & & & Mean $34.9 \pm 10.5$ & Type 1 & 36.5 & 1.0 (PDR) 5.73 (DME) \\
\hline & & & Mean $64.6 \pm 10.8$ & Type 2 & 26.1 & 0.56 (PDR) 6.44 (DME) \\
\hline \multirow{3}{*}{$\begin{array}{l}\text { Dutra Medeiros } \\
\text { (2015) [66] }\end{array}$} & \multirow[t]{3}{*}{ Population } & \multirow[t]{3}{*}{ Portugal } & 52,739 & \multirow[t]{3}{*}{ Type 2} & \multirow[t]{3}{*}{16.3} & \multirow[t]{3}{*}{3.1} \\
\hline & & & Mean $69.1 \pm 11.1$ & & & \\
\hline & & & Range $\geq 45$ & & & \\
\hline \multirow[t]{3}{*}{ Hautala (2014) [12] } & \multirow[t]{3}{*}{ Population } & \multirow[t]{3}{*}{ Finland } & 172 & \multirow[t]{3}{*}{ Type 1} & \multirow[t]{3}{*}{93.6} & \multirow[t]{3}{*}{34.9 (PDR) } \\
\hline & & & Mean $30 \pm 3$ & & & \\
\hline & & & Range 22-35 & & & \\
\hline \multirow[t]{3}{*}{ Bertelsen (2013) [13] } & \multirow[t]{3}{*}{ Population } & \multirow[t]{3}{*}{ Norway } & 514 & Overall & 26.8 & 1.2 (PDR) 3.9 (DME) \\
\hline & & & Mean 66.4 & Type 1 & 78.0 & \\
\hline & & & Range 46-87 & Type 2 & 25.0 & \\
\hline Knudsen (2006) [14] & Population & Denmark & 984 & Overall & 48.8 & \\
\hline & & & Median 37.3 & Type 1 & 53.8 & 2.9 (PPDR) 5.6 (PDR) \\
\hline & & & IQR 19.0-48.5 & & & \\
\hline & & & Median 58.1 & Type 2 & 38.7 & 3.6 (PPDR) 0.9 (PDR) \\
\hline & & & IQR 15.0-65.0 & & & 12.8 (CSME) \\
\hline Dedov (2009) [15] & Population & Russia & 7186 & Overall & 45.9 & 8.1 (PPDR) 6.7 (PDR) \\
\hline & & & Median 38.0 & Type 1 & 54.6 & 9.1 (PPDR) 11.1 (PDR) \\
\hline & & & IQR 27.0-49.0 & & & \\
\hline & & & Median 59.0 & Type 2 & 34.2 & 7.2 (PPDR) 2.7 (PDR) \\
\hline & & & IQR 54.0-66.0 & & & \\
\hline North America & & & & & & \\
\hline Zhang (2010) [18] & Population & United States & 1006 & Unspecified & 28.5 & 4.4 \\
\hline & & of America & Range $\geq 40$ & & & \\
\hline Kempen (2004) [17] & Pooled population & United States & 4440 & Type 2 & 40.3 & 8.2 \\
\hline & trom 8 studies & of America & Range $\geq 40$ & & & \\
\hline Roy (2004) [16] & Pooled population & United States & 1384 & Type 1 & 79.1 & 31.2 \\
\hline & from 2 studies & of America & Range $\geq 18$ & & & \\
\hline Nathoo (2010) [67] & Population & Canada & 394 & Unspecified & 27.2 & 2.3 (PDR) 2.0 (CSME) \\
\hline & & & Mean 58.8 & & & \\
\hline & & & Range 10-100 & & & \\
\hline South America & & & & & & \\
\hline Schellini (2014) [206] & Population & Brazil & 407 & Type 2 & 7.62 & Not investigated \\
\hline & & & Mean $51.8 \pm 13.6$ & & & \\
\hline & & & Range $\geq 30$ & & & \\
\hline Esteves (2009) [68] & Hospital & Brazil & 437 & Type 1 & 44.4 & 3.0 (PPDR) 22.2 (PDR) \\
\hline & & & Mean $26.8 \pm 7.8$ & & & y. \\
\hline & & & Range $\geq 18$ & & & \\
\hline Villena (2011) [69] & Hospital & Peru & 1222 & Type 2 & 23.1 & 1.6 (PPDR) 2.8 (PDR) \\
\hline & & & Median 59.0 & & & SIVIE) \\
\hline & & & IQR 52.0-67.0 & & & \\
\hline
\end{tabular}


Table 1 Prevalence of diabetic retinopathy among diabetic subjects (Continued)

\begin{tabular}{|c|c|c|c|c|c|c|}
\hline \multicolumn{7}{|l|}{ Africa } \\
\hline \multirow[t]{3}{*}{ Thomas (2013) [70] } & \multirow[t]{3}{*}{ Hospital } & \multirow[t]{3}{*}{ South Africa } & 5565 & Overall & 25.8 & 7.5 \\
\hline & & & Mean $35.4 \pm 15.4$ & Type 1 & 36.9 & 9.7 \\
\hline & & & Mean $56.8 \pm 11.8$ & Type 2 & 21.4 & 6.6 \\
\hline \multirow[t]{3}{*}{ Kahloun (2014) [33] } & \multirow[t]{3}{*}{ Hospital } & \multirow[t]{3}{*}{ Tunisia } & 2320 & \multirow[t]{3}{*}{ Type 1 and 2} & \multirow[t]{3}{*}{26.3} & \multirow{3}{*}{$\begin{array}{l}5.4 \text { (PPDR) } 3.4 \text { (PDR) } \\
4.2 \text { (CSME) }\end{array}$} \\
\hline & & & Mean 54.5 & & & \\
\hline & & & Range 10-92 & & & \\
\hline \multirow[t]{2}{*}{ Mathenge (2014) [34] } & \multirow[t]{2}{*}{ Population } & \multirow[t]{2}{*}{ Kenya } & 195 & \multirow[t]{2}{*}{ Unspecified } & \multirow[t]{2}{*}{35.9} & \multirow{2}{*}{$\begin{array}{l}13.9 \text { (PPDR + PDR) } \\
4.1 \text { (CSME) }\end{array}$} \\
\hline & & & Range $\geq 50$ & & & \\
\hline Sharew (2013) [35] & Hospital & Ethiopia & 324 & Unspecified & 41.4 & 7.3 \\
\hline \multicolumn{7}{|l|}{ Oceania } \\
\hline \multirow[t]{2}{*}{ Kaidonis (2014) [71] } & \multirow{2}{*}{$\begin{array}{l}\text { Pooled population } \\
\text { from } 11 \text { studies }\end{array}$} & \multirow[t]{2}{*}{ Australia } & 12,666 & \multirow[t]{2}{*}{ Type 1 and 2} & \multirow[t]{2}{*}{30.4} & \multirow[t]{2}{*}{7.5 (PDR and/or DME) } \\
\hline & & & Range $\geq 15$ & & & \\
\hline $\begin{array}{l}\text { Papali'i-Curtin } \\
\text { (2013) [207] }\end{array}$ & Population & New Zealand & 5647 & Unspecified & 19.0 & 0.4 (PDR) \\
\hline \multirow[t]{2}{*}{ Win Tin (2014) [208] } & \multirow[t]{2}{*}{ Population } & \multirow{2}{*}{$\begin{array}{l}\text { Pacific Islands } \\
\text { (Vanuatu, Nauru, } \\
\text { Solomon Islands) }\end{array}$} & 459 & \multirow[t]{2}{*}{ Type 2} & \multirow[t]{2}{*}{47.1} & \multirow[t]{2}{*}{ Not investigated } \\
\hline & & & Mean 54 & & & \\
\hline
\end{tabular}

$D R$ diabetic retinopathy, VTDR vision-threatening diabetic retinopathy, $P D R$ proliferative diabetic retinopathy, DME diabetic macular edema, $P P D R$ preproliferative diabetic retinopathy, CSME clinically significant macular edema, IQR interquartile range

and developed versus developing countries are not possible due to the lack of population-based cohort studies in Asia and many developing countries. In the USA, the Wisconsin Epidemiologic Study of Diabetic Retinopathy (WESDR) found that among patients with insulindependent diabetes with onset before the age of 30, who are presumed to have type 1 diabetes, the 4-year cumulative incidence of DR was $59.0 \%$ [41]. At 10, 14 and 25 years, cumulative incidence of DR in the same cohort rose to $89.3 \%$ [42], $95.9 \%$ [43], and $97 \%$ [44], respectively. Similar observations were made in the Danish Cohort of Pediatric Diabetes 1987 (DCPD1987), which reported a 16-year cumulative incidence of $95.1 \%$ [45]. While these cohorts have long follow-up times, it should be noted that the participants were recruited between 1979 and 1989. The incidence reported in these studies may not reflect actual DR incidence today, owing to significant advancements in retinopathy diagnosis techniques and risk factor management in the past three decades. For example, in a UK cohort recruited between 1991 and 1999, 6-year cumulative incidence of DR in patients with type 1 diabetes was estimated to be only $45.3 \%$ [46]. A separate UK study, involving only newly diagnosed cases of type 1 diabetes recruited between 2000 and 2007, found 9year cumulative incidence of DR to be only $23.9 \%$ [47]. In Finland, the incidence of VTDR was reported to be decreasing in patients with type 1 diabetes [48]. In this study, patients who were diagnosed with diabetes from 1980 to 1984 had $47 \%$ reduced risk of VTDR as compared to patients diagnosed from 1975 to 1979, after adjusting for gender and age of diabetes onset. The reduction in risk was even greater in the cohort diagnosed from 1985 onwards, at $64 \%$. Overall, these studies indicate that while almost all patients with type 1 diabetes may eventually develop DR over time, the incidence of DR and VTDR among patients with type 1 diabetes is probably on the decline.

In the UK, population studies involving patients with type 2 diabetes estimated cumulative incidence of DR to be $26.0 \%$ at 4 years [49] $38.1-41.0 \%$ at 6 years [50, 51], and $66 \%$ at 10 years [52]. These findings seem comparable to that found in US population studies, which estimated cumulative incidence of DR to be $22.5-34.0 \%$ at 4 years $[53,54]$ and $72.3 \%$ at 14 years [55], despite differences in ethnicity and age of the cohorts at the time of diabetes diagnosis. Cohorts in Australia [56], Barbados [57] and Mauritius [58] report cumulative incidence that is similar to the UK and US studies. In contrast, the 4-year cumulative incidence of DR in a Spanish cohort is much lower, estimated at $8.1 \%$ [59]. Age and duration of diabetes are comparable between the US, UK and Spanish studies, and this significant difference in incidence is attributed to unusually good glycemic control within the Spanish cohort, with mean HbA1c at $7 \%$, with $55 \%$ of the cohort achieving HbA1c of less than $7 \%$. In contrast, patients in one of the US cohorts [53] had HbA1c of $9.9 \%$ on average.

As with prevalence, incidence data from Asia is restricted only to that of type 2 diabetes. A populationbased study in urban Shanghai, China, found the 5-year cumulative incidence to be much higher than in the US and UK, at $46.9 \%$, of which more than a third of it is 
Table 2 Incidence of diabetic retinopathy among diabetic subjects

\begin{tabular}{|c|c|c|c|c|c|c|c|}
\hline Author (Year) & Type of study & Location & $\begin{array}{l}\text { Sample size, } \\
\text { Age in years }\end{array}$ & $\begin{array}{l}\text { Diabetes } \\
\text { type }\end{array}$ & $\begin{array}{l}\text { Follow-up } \\
\text { time in years }\end{array}$ & $\begin{array}{l}\text { Cumulative incidence } \\
\text { of DR, } \%(95 \% \mathrm{Cl})\end{array}$ & $\begin{array}{l}\text { Incidence of } \\
\text { VTDR (\%) }\end{array}$ \\
\hline \multicolumn{8}{|l|}{ Asia } \\
\hline \multirow[t]{2}{*}{ Xu (2014) [75] } & \multirow[t]{2}{*}{ Population } & \multirow[t]{2}{*}{ China } & 2602 & \multirow[t]{2}{*}{ Unspecified } & \multirow[t]{2}{*}{10} & \multirow[t]{2}{*}{$4.2(3.45-5.03)^{* *}$} & \multirow[t]{2}{*}{ Not investigated } \\
\hline & & & Mean $64.6 \pm 9.7$ & & & & \\
\hline \multirow[t]{2}{*}{ Jin (2014) [98] } & \multirow[t]{2}{*}{ Population } & \multirow[t]{2}{*}{ China } & 322 & \multirow[t]{2}{*}{ Type 2} & \multirow[t]{2}{*}{5} & \multirow[t]{2}{*}{46.9} & 13.9 (Severe NPDR) \\
\hline & & & Mean $66.1 \pm 13.2$ & & & & 4.6 (PDR) \\
\hline \multirow[t]{2}{*}{ Tam (2009) [60] } & \multirow[t]{2}{*}{ Hospital } & \multirow[t]{2}{*}{ Hong Kong } & 212 & \multirow[t]{2}{*}{ Type 2} & \multirow[t]{2}{*}{4} & \multirow[t]{2}{*}{20.3} & \multirow[t]{2}{*}{0.47 (PDR) } \\
\hline & & & Mean $55.2 \pm 9.5$ & & & & \\
\hline \multirow[t]{2}{*}{ Song (2011) [61] } & \multirow[t]{2}{*}{ Hospital } & Hong Kong & 3647 & Type 2 & 4 & 15.2 & 0.03 \\
\hline & & & $\begin{array}{l}\text { Mean } 62.60 \pm \\
9.58\end{array}$ & & & & \\
\hline Kawasaki & Hospital & Japan & 1221 & Type 2 & 8 & 26.6 & Not investigated \\
\hline$(2011)[62]$ & & & Mean $58.2 \pm 6.9$ & & & & \\
\hline Kajiwara & Hospital & Japan & 383 & Type 2 & $5.8 \pm 2.5$ & 58.5/1000 person & Not investigated \\
\hline & & & Mean $59.4 \pm 11.0$ & & & & \\
\hline Tsugawa & Hospital & Japan & 1083 & Unspecified & 3 & 15.7 & Not investigated \\
\hline & & & Mean $51.0 \pm 11.7$ & & & & \\
\hline Ahmed & Hospital & Bangladesh & 977 & Type 2 & 15 & $50.6(47.5-53.8)$ & Not investigated \\
\hline & & & Mean $41 \pm 8$ & & & & \\
\hline Middle East & & & & & & & \\
\hline Manaviat & Hospital & Iran & 120 & Type 2 & 4 & $47.5(38.6-56.4)$ & Not investigated \\
\hline & & & Mean $55.2 \pm 9.6$ & & & & \\
\hline Janghorbani & Hospital & Iran & 549 & Type 2 & $5.1 \pm 2.1$ & 45.4 & Not investigated \\
\hline & & & Mean & & (retrospective) & & \\
\hline & & & $45.7 \pm 9.3$ & & & & \\
\hline Europe & & & & & & & \\
\hline Stratton & Population & United & 1216 & Type 2 & 6 & 41 & Not investigated \\
\hline & & & Mean $52.2 \pm 8.5$ & & & & \\
\hline Younis & Population & United & 305 & Type 1 & 6 & $45.3(36.9-53.7)$ & $5.4(2.3-8.5)$ \\
\hline & & Kingdom & Median 30.2 & & & & \\
\hline & & & IQR 21.5-39.8 & & & & \\
\hline Younis & Population & United & 3743 & Type 2 & 6 & $38.1(35.1-41.2)$ & $6.1(4.4-7.8)$ \\
\hline & & & Median 63.4 & & & & \\
\hline & & & IQR 56.1-69.8 & & & & \\
\hline Jones & Population & United & 16,444 & Type 2 & 10 & 66 & 18.7 \\
\hline & & & Median 66.7 & & & & \\
\hline & & & IQR 58.0-74.5 & & & & \\
\hline Martin-Merino & Population & United & 1757 & Type 1 & 9 & 23.9 & 4.4 (DME) \\
\hline & & & Mean 19.1 & & & & \\
\hline & & & 63,226 & Type 2 & & 27.8 & 3.6 (DME) \\
\hline & & & Mean 61.3 & & & & \\
\hline Thomas & Population & United & 49,763 & Type 2 & 4 & 26.0 & 0.7 \\
\hline (2012) [49] & & Kingdom & Mean $60.2 \pm 11.3$ & & & & \\
\hline Perol & Hospital & France & 236 & Unspecified & 3 & $14.0(9.5-18.4)$ & 0 \\
\hline & & & Mean $54.0 \pm 12.8$ & & & & \\
\hline
\end{tabular}


Table 2 Incidence of diabetic retinopathy among diabetic subjects (Continued)

\begin{tabular}{|c|c|c|c|c|c|c|c|}
\hline \multirow{2}{*}{$\begin{array}{l}\text { Romero-Aroca } \\
\text { (2011) [77] }\end{array}$} & \multirow[t]{2}{*}{ Hospital } & \multirow[t]{2}{*}{ Spain } & 334 & \multirow[t]{2}{*}{ Type 1} & \multirow[t]{2}{*}{10} & \multirow[t]{2}{*}{35.9} & \multirow[t]{2}{*}{11.07 (DME) } \\
\hline & & & Mean $25.7 \pm 11.7$ & & & & \\
\hline \multirow{2}{*}{$\begin{array}{l}\text { Salinero-Fort } \\
\text { (2013) [59] }\end{array}$} & \multirow[t]{2}{*}{ Population } & \multirow[t]{2}{*}{ Spain } & 2405 & \multirow[t]{2}{*}{ Type 2} & \multirow[t]{2}{*}{4} & \multirow[t]{2}{*}{8.07 (7.04-9.22) } & \multirow{2}{*}{$\begin{array}{l}2.8 \text { (PDR) } \\
1.2 \text { (DME) }\end{array}$} \\
\hline & & & Mean $67.5 \pm 10.6$ & & & & \\
\hline \multirow{2}{*}{$\begin{array}{l}\text { Henricsson } \\
\text { (2003) [111] }\end{array}$} & \multirow[t]{2}{*}{ Population } & \multirow[t]{2}{*}{ Sweden } & 627 & \multirow{2}{*}{$\begin{array}{l}\text { Types } 1 \text { and } \\
2\end{array}$} & \multirow[t]{2}{*}{10} & \multirow[t]{2}{*}{39} & \multirow[t]{2}{*}{1.8 (PDR) } \\
\hline & & & Mean $35.3 \pm 5.8$ & & & & \\
\hline \multirow{2}{*}{$\begin{array}{l}\text { Broe (2014) } \\
\text { [45] }\end{array}$} & \multirow[t]{2}{*}{ Population } & \multirow[t]{2}{*}{ Denmark } & 185 & \multirow[t]{2}{*}{ Type 1} & \multirow[t]{2}{*}{16} & \multirow[t]{2}{*}{95.1} & \multirow[t]{2}{*}{ Not investigated } \\
\hline & & & Mean $7.5 \pm 3.7$ & & & & \\
\hline \multicolumn{8}{|l|}{ North America } \\
\hline \multirow[t]{2}{*}{ Lee (1992) [55] } & \multirow{2}{*}{$\begin{array}{l}\text { Population } \\
\text { (Oklahoma } \\
\text { Indians) }\end{array}$} & \multirow{2}{*}{$\begin{array}{l}\text { United States } \\
\text { of America }\end{array}$} & 380 & \multirow[t]{2}{*}{ Type 2} & 14 & 72.3 & 15.4 (PDR) \\
\hline & & & Mean $48.2 \pm 8.4$ & & & 12.5 improved & \\
\hline Klein (1998) & Population & United States & 634 & Type 1 & 14 & 95.9 (93.2-98.6) & $26.1(22.6-29.6)$ \\
\hline & & ol Amenicd & Mean $14.2 \pm 7.4$ & & & & (UIVIE) \\
\hline Tudor (1998) & Population & United States & 169 & Type 2 & 4 & 22.5 & Not investigated \\
\hline & & of America & Mean 58.1 & & & & \\
\hline Varma (2010) [54] & Population & United States & 775 & Unspecified & 4 & $34.0(30.0-38.0)$ & 5.4 (3.8-7.1) (DME) \\
\hline & & & Mean $58 \pm 9.7$ & & & & \\
\hline Oceania & & & & & & & \\
\hline Cikamatana & Population & Australia & 150 & Unspecified & 5 & $22.2(14.1-32.2)$ & Not investigated \\
\hline (2007) [50] & & & Mean $66.2 \pm 8.4$ & & & & \\
\hline Others & & & & & & & \\
\hline Leske & Population & Barbados & 436 & Types 1 and & 9 & $39.6(33.6-45.5)$ & 8.3 \\
\hline (2006) & & & Mean $57.6 \pm 9.4$ & & & & \\
\hline Tapp & Population & Mauritius & 227 & Unspecified & 6 & 23.8 & 0.4 (PDR) \\
\hline & & & Mean $50 \pm 11$ & & & & \\
\hline
\end{tabular}

$D R$ diabetic retinopathy, VTDR vision-threatening diabetic retinopathy, $C /$ confidence interval, NPDR nonproliferative diabetic retinopathy, PDR proliferative diabetic retinopathy, DME diabetic macular edema

${ }^{* *}$ Cumulative incidence of DR among total sample, incidence among participants with diabetes not reported

VTDR. This may just be due to differences in known diabetes duration of the cohorts; the Chinese cohort has diabetes duration of 11 years on average at baseline assessment, while studies in the US and UK report diabetes duration to be 4 to 7 years on average. More prospective studies are warranted to compare the incidence of DR in Asia with that observed in Europe or the US.

\section{Progression and regression of DR}

A large number of cohort studies have investigated progression and regression of DR [44, 45, 52-54, 56-58, 60-62]. Disease severity was most often classified by the Early Treatment Diabetic Retinopathy Study (ETDRS) classification for DR severity [63]. The cohort with the longest follow-up time was the WESDR cohort, which reported 25-year progression of DR in patients with type 1 diabetes [44]. In this study, DR severity was assigned a level by concatenating the severity grade in both eyes, with the worse eye given greater weight. This created a 15-step scale, and progression was defined as increase in severity of 2 steps or more. Some other studies assigned DR severity based on the severity grade in the worse eye alone. The findings on DR progression and regression from the various cohort studies are summarized in Table 3. Four to six-year cumulative incidence of 2-step progression among the studies ranged from 24.1 to $38.9 \%$, which increased to 64.1 and $83.1 \%$ in studies with 16-year or 25-year follow-up.

In general, progression was much more common than regression. Two Asian cohort studies, both hospital-based and carried out in Hong Kong, investigated the regression of DR. One of the studies found 4-year progression of DR to be $34.7 \%$ and 4-year regression to be $13.2 \%$ [60], which is similar to that seen in the population-based US cohorts. However, the other study found 4-year regression to be substantially higher ( $45.8 \%$ ) and progression to be lower (6.6 \%) [61]. This study defined progression or regression by 1-step change in severity, while most of the 
Table 3 Progression and regression of diabetic retinopathy

\begin{tabular}{|c|c|c|c|c|c|c|}
\hline Author (Year) & Method of severity grading & Progression intervals & $\begin{array}{l}\text { Criteria for progression } \\
\text { or regression }\end{array}$ & $\begin{array}{l}\text { Progression of } \\
\text { DR (\%) }\end{array}$ & $\begin{array}{l}\text { Progression from } \\
\text { NPDR to PDR (\%) }\end{array}$ & Regression of DR (\%) \\
\hline \multicolumn{7}{|l|}{ Asia } \\
\hline Tam (2009) [60] & $\begin{array}{l}\text { Concatenated ETDRS severity } \\
\text { of both eyes, with } 11 \text { levels }\end{array}$ & Cumulative at 4 years & 2-step & 34.7 & 9.9 & 13.2 \\
\hline Song (2011) [61] & Eye with worse ETDRS severity & Cumulative at 4 years & 1-step & 6.6 & Not investigated & 45.8 \\
\hline Kawasaki (2011) [62] & $\begin{array}{l}\text { Mild DR to at least severe NPDR according } \\
\text { to ETDRS }\end{array}$ & Cumulative at 8 years & N/A & N/A & 15.9 & Not investigated \\
\hline \multicolumn{7}{|l|}{ Europe } \\
\hline \multirow[t]{2}{*}{ Jones (2012) [52] } & \multirow[t]{2}{*}{ Eye with worse ETDRS severity } & Cumulative at 5 years & \multirow[t]{2}{*}{ Not stated } & \multirow[t]{2}{*}{ Data irretrievable } & 6.1 & \multirow[t]{2}{*}{ Not investigated } \\
\hline & & Cumulative at 10 years & & & 9.6 & \\
\hline Broe (2014) [45] & Eye with worse ETDRS severity & Cumulative at 16 years & 2-step & 64.1 & 31.0 & 0 \\
\hline \multicolumn{7}{|l|}{ North America } \\
\hline Tudor (1998) [53] & Eye with worse ETDRS severity & Cumulative at 4 years & 2-step & 24.1 & Not investigated & 13.3 \\
\hline Varma (2010) [54] & $\begin{array}{l}\text { Concatenated ETDRS severity of both eyes, } \\
\text { with } 15 \text { levels }\end{array}$ & Cumulative at 4 years & 2-step & 38.9 & 5.3 & 14.0 \\
\hline \multirow[t]{5}{*}{ Klein (2008) [44] } & \multirow{5}{*}{$\begin{array}{l}\text { Concatenated ETDRS severity of both eyes, } \\
\text { with } 15 \text { levels }\end{array}$} & Between 0 to 4 years & \multirow[t]{5}{*}{ 2-step } & 13.5 annually & 2.5 annually & 3.0 annually \\
\hline & & Between 4 to 10 years & & 13.0 annually & 4.0 annually & 0.8 annually \\
\hline & & Between 10 to 14 years & & 12.0 annually & 2.5 annually & 0.4 annually \\
\hline & & Between 14 to 25 years & & 2.4 annually & 1.5 annually & 0.4 annually \\
\hline & & Cumulative at 25 years & & 83.1 & 42.0 & 17.8 \\
\hline \multicolumn{7}{|l|}{ Oceania } \\
\hline Cikamatana (2007) [56] & $\begin{array}{l}\text { Concatenated ETDRS severity of both eyes, } \\
\text { with } 15 \text { levels }\end{array}$ & Cumulative at 5 years & 1-step & 25.9 & 4.1 & Not reported \\
\hline \multicolumn{7}{|l|}{ Others } \\
\hline Leske (2006) [57] & $\begin{array}{l}\text { Mild or moderate DR to at least severe NPDR } \\
\text { according to ETDRS }\end{array}$ & Cumulative at 9 years & N/A & N/A & 8.2 & Not investigated \\
\hline Tapp (2006) [58] & $\begin{array}{l}\text { Mild or moderate DR to at least severe NPDR } \\
\text { according to ETDRS }\end{array}$ & Cumulative at 6 years & N/A & 27.7 & 5.2 & Not investigated \\
\hline
\end{tabular}

DR diabetic retinopathy, NPDR nonproliferative diabetic retinopathy, PDR proliferative diabetic retinopathy, ETDRS Early Treatment for Diabetic Retinopathy Study, N/A not available 
other studies defined progression or regression by 2-step changes in severity. Moreover, this study was based in a community optometry clinic. Hence, the population sample may be biased towards patients with mild baseline severity of DR, as patients with more severe disease may have been referred to tertiary hospitals for follow-up. Indeed, $91.7 \%$ of patients with DR at baseline in this study had only mild NPDR, and the 1-step regression of mild NPDR to no DR accounted for the majority of the regression observed in this study. The results of this study are hence not directly comparable with that of the other cohorts, but it highlights the high probability of disease regression in patients with only mild NPDR. The absence of data on population-based cohorts in Asia also precludes direct comparison of progression and regression rates between Asian and Western populations.

\section{Prevalence of DME}

In most studies, DME was defined by hard exudates in the presence of microaneurysms and blot hemorrhages within one disc diameter of the foveal center. Clinically significant macular edema (CSME) is the more severe spectrum of DME, and was defined by the presence of edema within $500 \mu \mathrm{m}$ of the foveal center, or focal photocoagulation scars present in the macular area. The prevalence of DME among recent cross-sectional studies is summarized in Table 4. Among the population-based studies, prevalence of DME among patients with type 1 diabetes was between 4.2 and $7.9 \%$. In patients with type 2 diabetes, it was between 1.4 and $12.8 \%$. Non-stereoscopic fundus photography was used in most studies, which affects the accuracy of DME assessment. About half of the studies defined macular edema using the CSME criteria, and hence only the more severe spectrum of DME was captured in these studies. Overall, the heterogeneity in methodology causes comparison of prevalence between these studies to be a challenge. The prevalence of DME among patients with diabetes is generally much lower than that of DR $[11,13$, 14, 16-18, 20, 21, 24, 26, 27, 32-35, 39, 64-71]. There was no observable difference between prevalence of DME between Western or Eastern populations.

In the Diabetic Retinopathy Screening Service for Wales, a high prevalence of DR (56.0\% in type 1 diabetes, $30.3 \%$ in type 2 diabetes) was reported, but the prevalence of DME was not found to be higher than other studies ( $4.2 \%$ in type 1 diabetes, $1.4 \%$ in type 2 diabetes) [10].

There were a few outliers among the studies that reported exceptionally high prevalence of DME. In Kenya, a population-based study found a prevalence of DME of $33.3 \%$ among participants with diabetes [34], while a Canadian study found DME prevalence to be $15.7 \%$. It is difficult to ascertain if this abnormally - high observed prevalence is due to genuinely high prevalence in these populations or a difference in methodology. Of note, clinical stereoscopic fundus examination by an ophthalmologist was carried out in both of these studies and factored in the diagnosis of DME whereas most studies relied on non-stereoscopic fundus photographs alone, thus raising the question if prevalence studies using non-stereoscopic fundus photographs may be severely underdiagnosing DME. In patients with newly diagnosed diabetes, observed prevalence of DME was almost non-existent, with studies reporting it to be within 0 to $0.8 \%[21,39]$. A Cochrane review of prevalence of DME assessed by optical coherence tomography (OCT) has found a large range of prevalence rates (19-65\%) [72]. Of note, none of the studies included in the review were population-based studies. OCT-detected DME was found to have a great degree of disagreement with the clinical definition of CSME, and not all patients who had macular thickening detected on OCT progressed to have clinical DME, hence its validity as a diagnostic tool in epidemiologic studies is questionable.

\section{Incidence of DME}

Cohort studies that investigated DME incidence are summarized in Table 5. Only studies conducted in the US and Europe investigated DME incidence. The WESDR cohort of patients with type 1 diabetes had the longest follow-up time of 25 years [73]. Interestingly, cumulative incidence of DME and CSME in this cohort seemed to plateau at the 14-year mark (DME $26.1 \%$, CSME $17.0 \%$ ), with the latter 11 years adding minimally to the 25-year cumulative incidence (DME $29 \%$, CSME $17 \%$ ). Data available on DME incidence in type 2 diabetes is limited and inconsistent $[50,52,59]$.

\section{Risk factors for DR and DME}

DR and DME share many common risk factors. Incidence-derived risk factors for DR and DME reported in the various cohort studies are summarized in Table 6. The major and established risk factors have been reviewed extensively before [74]. The most pertinent observations will be highlighted again in this review, with updates from the latest literature. Novel risk factors were also reviewed.

\section{Non-modifiable risk factors \\ Duration of diabetes}

Cohort studies with the longest follow-up times found that almost all patients with type 1 diabetes develop some degree of retinopathy if duration of disease exposure is long enough $[44,45]$. This relationship is not as clear in cohort studies on type 2 diabetes, probably due to the competing risk of mortality in patients with type 2 diabetes, who are older and may have more age-related comorbidities. Nevertheless, many studies, both in type 1 and type 2 diabetes [49, 52, 59, 75-77], found disease 
Table 4 Prevalence of diabetic macular edema among diabetic subjects

\begin{tabular}{|c|c|c|c|c|c|}
\hline Author (Year) & Type of study & Location & $\begin{array}{l}\text { Type of } \\
\text { diabetes }\end{array}$ & $\begin{array}{l}\text { Prevalence } \\
(\%)\end{array}$ & $\begin{array}{l}\text { Definition of macular } \\
\text { edema }\end{array}$ \\
\hline \multirow[t]{3}{*}{ Yau (2012) [3] } & \multirow[t]{3}{*}{ Meta-analysis } & \multirow[t]{3}{*}{ Global } & Overall & 7.48 & DME and/or CSME \\
\hline & & & Type 1 & 14.25 & DME and/or CSME \\
\hline & & & Type 2 & 5.57 & DME and/or CSME \\
\hline Xie (2008) [214] & Population & China & Unspecified & 4 & CSME \\
\hline \multirow[t]{2}{*}{ Jee (2013) [20] } & \multirow[t]{2}{*}{ Population } & \multirow[t]{2}{*}{ South Korea } & \multirow[t]{2}{*}{ Type 2} & 2.8 & DME \\
\hline & & & & 1.4 & CSME \\
\hline \multirow[t]{2}{*}{ Wong (2008) [39] } & \multirow[t]{2}{*}{ Population } & \multirow[t]{2}{*}{ Singapore } & \multirow[t]{2}{*}{ Type 2} & 5.7 & DME \\
\hline & & & & 3.0 & CSME \\
\hline \multirow[t]{2}{*}{ Zheng (2012) [24] } & \multirow[t]{2}{*}{ Population } & \multirow[t]{2}{*}{ Singapore } & \multirow[t]{2}{*}{ Type 2} & 7.2 & DME \\
\hline & & & & 4.5 & CSME \\
\hline Raman (2009) [21] & Population & India & Unspecified & 1.4 & CSME \\
\hline Thapa (2014) [32] & Hospital & Nepal & Unspecified & 5.78 & CSME \\
\hline Al-Rubeaan (2015) [64] & Population (Registry) & Saudi Arabia & Type 2 & 5.7 & DME \\
\hline \multirow[t]{2}{*}{ Al Ghamdi (2012) [26] } & \multirow[t]{2}{*}{ Population } & \multirow[t]{2}{*}{ Saudi Arabia } & \multirow[t]{2}{*}{ Unspecified } & 20.3 & $\begin{array}{l}\text { Scottish DR } \\
\text { Grading M1 }\end{array}$ \\
\hline & & & & 15.9 & $\begin{array}{l}\text { Scottish DR } \\
\text { Grading M2 (M2 } \\
\text { equivalent to DME) }\end{array}$ \\
\hline $\begin{array}{l}\text { Papakonstantinou (2015) } \\
\text { [27] }\end{array}$ & Population & Iran & Type 2 & 4.7 & CSME \\
\hline \multirow[t]{2}{*}{ Thomas (2015) [10] } & \multirow[t]{2}{*}{ Population } & \multirow[t]{2}{*}{ United Kingdom } & Type 1 & 4.2 & DME \\
\hline & & & Type 2 & 1.4 & DME \\
\hline Pugliese (2012) [65] & Hospital & Italy & Type 2 & 1.3 & DME \\
\hline \multirow[t]{2}{*}{ Pedro (2010) [11] } & \multirow[t]{2}{*}{ Population } & \multirow[t]{2}{*}{ Spain } & Type 1 & 5.73 & CSME \\
\hline & & & Type 2 & 6.44 & CSME \\
\hline Dutra Medeiros (2015) [66] & Population & Portugal & Type 2 & 1.4 & DME \\
\hline Bertelsen (2013) [13] & Population & Norway & Types 1 and 2 & 3.9 & DME \\
\hline \multirow[t]{2}{*}{ Knudsen (2006) [14] } & \multirow[t]{2}{*}{ Population } & Denmark & Type 1 & 7.9 & CSME \\
\hline & & & Type 2 & 12.8 & CSME \\
\hline Zhang (2010) [18] & Population & $\begin{array}{l}\text { United States of } \\
\text { America }\end{array}$ & Unspecified & 2.7 & CSME \\
\hline Varma (2014) [215] & Population & $\begin{array}{l}\text { United States of } \\
\text { America }\end{array}$ & Unspecified & 3.8 & DME \\
\hline Petrella (2012) [216] & Population (registry) & Canada & Type 1 and 2 & 15.7 & DME \\
\hline Nathoo (2010) [67] & Population & Canada & Unspecified & 2.0 & CSME \\
\hline Esteves (2009) [68] & Hospital & Brazil & Type 1 & 9.4 & CSME \\
\hline Villena (2011) [69] & Hospital & Peru & Type 2 & 2.3 & CSME \\
\hline Thomas (2013) [70] & Hospital & South Africa & Type 1 and 2 & 3.2 & DME \\
\hline Kahloun (2014) [33] & Hospital & Tunisia & Type 1 and 2 & 8.7 & DME \\
\hline & & & & 4.2 & CSME \\
\hline Mathenge (2014) [34] & Population & Kenya & Unspecified & 33.3 & DME \\
\hline & & & & 4.1 & CSME \\
\hline Sharew (2013) [35] & Hospital & Ethiopia & Unspecified & 6.0 & CSME \\
\hline Kaidonis (2014) [71] & $\begin{array}{l}\text { Pooled population from } 11 \\
\text { studies }\end{array}$ & Australia & Types 1 and 2 & 7.6 & DME \\
\hline
\end{tabular}


Table $\mathbf{5}$ Incidence of diabetic macular edema among diabetic subjects

\begin{tabular}{|c|c|c|c|c|c|c|}
\hline Author (Year) & Type of study & Location & Type of diabetes & $\begin{array}{l}\text { Follow-up time } \\
\text { in years }\end{array}$ & $\begin{array}{l}\text { Cumulative incidence, } \\
\%(95 \% \mathrm{Cl})\end{array}$ & $\begin{array}{l}\text { Definition of macular } \\
\text { edema }\end{array}$ \\
\hline Younis (2003) [46] & Population & United Kingdom & Type 1 & 6 & $3.2(0.8-5.7)$ & DME \\
\hline Younis (2003) [50] & Population & United Kingdom & Type 2 & 6 & $6.1(4.4-7.8)$ & DME \\
\hline Jones (2012) [52] & Population & United Kingdom & Type 2 & 10 & 1.5 & DME \\
\hline \multirow{2}{*}{$\begin{array}{l}\text { Martin-Merino } \\
(2012)[47]\end{array}$} & \multirow[t]{2}{*}{ Population } & \multirow[t]{2}{*}{ United Kingdom } & Type 1 & \multirow[t]{2}{*}{9} & 4.4 & DME \\
\hline & & & Type 2 & & 3.6 & DME \\
\hline Thomas (2012) [49] & Population & United Kingdom & Type 2 & 4 & 1.4 & DME \\
\hline Perol (2012) [213] & Hospital & France & Unspecified & 3 & 0 & DME \\
\hline $\begin{array}{l}\text { Romero-Aroca } \\
\text { (2011) [77] }\end{array}$ & Hospital & Spain & Type 1 & 10 & 11.07 & DME \\
\hline $\begin{array}{l}\text { Salinero-Fort } \\
\text { (2013) [59] }\end{array}$ & Population & Spain & Type 2 & 4 & 0.01 & DME \\
\hline \multirow[t]{2}{*}{ Klein (1998) [43] } & \multirow[t]{2}{*}{ Population } & \multirow[t]{2}{*}{ United States of America } & \multirow[t]{2}{*}{ Type 1} & \multirow[t]{2}{*}{14} & $26.1(22.6-29.6)$ & DME \\
\hline & & & & & $17.0(14.1-19.9)$ & CSME \\
\hline \multirow[t]{2}{*}{ Klein (2009) [73] } & \multirow[t]{2}{*}{ Population } & \multirow[t]{2}{*}{ United States of America } & \multirow[t]{2}{*}{ Type 1} & \multirow[t]{2}{*}{25} & 29 & DME \\
\hline & & & & & 17 & CSME \\
\hline \multirow[t]{2}{*}{ Varma (2010) [54] } & \multirow[t]{2}{*}{ Population (Latino) } & \multirow[t]{2}{*}{ United States of America } & \multirow[t]{2}{*}{ Unspecified } & \multirow[t]{2}{*}{4} & $5.4(3.8-7.1)$ & $\begin{array}{l}\text { DME exclusive } \\
\text { of CSME }\end{array}$ \\
\hline & & & & & $7.2(5.2-9.1)$ & CSME \\
\hline Leske (2006) [57] & Population & Barbados & Types 1 and 2 & 9 & $8.7(5.4-12.0)$ & CSME \\
\hline
\end{tabular}

$D R$ diabetic retinopathy, DME diabetic macular edema, CSME clinically significant macular edema, $C I$ confidence interval

duration to be a significant risk factor for DR, and this is independent of adequacy of glycemic control.

\section{Puberty and pregnancy}

Puberty is a well-known risk factor for DR in type 1 diabetes. Pre-pubertal years of diabetes exposure contributes to added risk of DR $[78,79]$, but it seems that it is disease exposure during puberty itself, when the body is undergoing rapid development and maturation, that has the greater impact on the risk of DR. In Finland, the FinnDiane Study Group found that onset of diabetes during pubertal or post-pubertal age increases risk of developing severe retinopathy requiring laser treatment when compared to patients with pre-pubertal onset of diabetes [80]. This was particularly significant among the male participants. Biological pathways that may contribute to this phenomenon include the transforming growth factor beta (TGF- $\beta$ ) signaling pathway, which is an important mediator of renal microvascular damage [81]. Androgens promote and accelerate TGF- $\beta$ transcriptional activity, which can explain the male preponderance. However, evidence of activation of similar pathways in retinal vessels is lacking.

DR and DME can progress rapidly during pregnancy, especially in patients with type 1 diabetes. A recent study found progression of DR in pregnancy to be almost 3 times as likely to occur in mothers with type 1 diabetes as mothers with type 2 diabetes ( 31.3 vs. $11.7 \%, \mathrm{p}=0.001$ ) [82]. This progression is often transient and accompanied by rapid regression of $\mathrm{DR}$ in the postpartum period. At the end of 6.5 years of follow-up on average, prevalence and severity of retinopathy was comparable between women with pregnancies and women without pregnancies [83]. Possible mechanisms behind the progression of DR in pregnancy include both hormonal and immune theories $[84,85]$.

\section{Modifiable risk factors \\ Hyperglycemia}

Hyperglycemia is one of the most important risk factors for DR and DME. A meta-analysis of three large population-based studies found a graded relationship between the level of glycemia and frequency of retinopathy signs [86]. The United Kingdom Prospective Diabetes Study (UKPDS) and the Diabetes Control and Complications Trial (DCCT) provided strong evidence that tight control of glycemia (HbA1c $<7 \%$ ) reduces the risk of development and progression of DR in both type 1 and type 2 diabetes [87]. The DCCT showed that intensive glycemic control reduced the incidence of retinopathy by $76 \%$ and progression from early to advanced retinopathy by $54 \%$ [88]. This highlights that strict glycemic control is 
Table 6 Incidence-derived risk factors for the development of diabetic retinopathy in cohort studies

\begin{tabular}{|c|c|c|}
\hline Risk factor & Author (Year) & Strength of association \\
\hline \multirow[t]{4}{*}{ Age } & $\mathrm{Xu}(2014)[75]$ & OR $(95 \% \mathrm{Cl})=1.00(0.98-1.02)$ per year increase \\
\hline & Ahmed (2012) [210] & HR $(95 \% \mathrm{Cl})=1.29(1.07-1.58)$ per year \\
\hline & Janghorbani (2003) [212] & HR $(95 \% \mathrm{Cl})=1.03(1.006-1.04)$ per year increase \\
\hline & Jones (2012) [52] & $\begin{array}{l}\text { Compared to } 40-70 \text { years, HR }(95 \% \mathrm{Cl})=1.49(1.09-2.05) \text { for }<40 \text { years; } \\
1.26(1.00-1.27) \text { for }>70 \text { years }\end{array}$ \\
\hline \multirow[t]{3}{*}{ Gender } & Xu (2014) [75] & OR $(95 \% \mathrm{Cl})=1.32(0.88-1.96){ }^{*}$ reference gender not reported \\
\hline & Kajiwara (2014) [76] & HR $(95 \% \mathrm{Cl})=1.85(1.06-3.24)$ for female \\
\hline & Ahmed (2012) [210] & $\mathrm{HR}(95 \% \mathrm{Cl})=1.08(0.91-1.29){ }^{*}$ reference gender not specified \\
\hline Smoking & Stratton (2001) [51] & OR $(95 \% \mathrm{Cl})=0.63(0.48-0.82)$ if current smoker \\
\hline \multirow[t]{6}{*}{ Duration of diabetes } & Xu (2014) [75] & OR $(95 \% \mathrm{Cl})=1.16(1.10-1.22)$ per year increase \\
\hline & Kajiwara (2014) [76] & OR $(95 \% \mathrm{Cl})=1.13(1.09-1.17)$ per year increase \\
\hline & Romero-Aroca (2011) [77] & OR $(95 \% \mathrm{Cl})=8.90(4.83-17.4)$ for $\leq 15$ years vs. $>15$ years \\
\hline & Jones (2012) [52] & $\begin{array}{l}\text { Compared to }<10 \text { years, } \mathrm{HR}(95 \% \mathrm{Cl})=1.21(1.01-1.44) \text { for } \\
10-20 \text { years; } 0.93(0.68-1.26) \text { if } \geq 20 \text { years }\end{array}$ \\
\hline & Thomas (2012) [49] & $\begin{array}{l}\text { Compared to }<5 \text { years, } \mathrm{HR}(95 \% \mathrm{Cl})=1.29(1.23-1.34) \text { for } \\
5-9 \text { years; } 1.68(1.59-1.77) \text { for } 10 \text { years }\end{array}$ \\
\hline & Salinero-Fort (2013) [59] & $\begin{array}{l}\text { Compared to }<6 \text { years, HR }(95 \% \mathrm{Cl})=1.22(0.88-1.70) \text { for } \\
7-14 \text { years; } 1.64(1.05-2.57) \text { for } 15-22 \text { years; } 2.00(1.18-3.39) \\
\text { for } 22 \text { years }\end{array}$ \\
\hline \multirow[t]{11}{*}{$\mathrm{HbA} 1 \mathrm{C}$} & Xu (2014) [75] & OR $(95 \% \mathrm{Cl})=1.73(1.35-2.21)$ per $1 \%$ increase \\
\hline & Jin (2014) [98] & OR $(95 \% \mathrm{Cl})=1.12(1.01-1.24)$ per $1 \%$ increase \\
\hline & $\operatorname{Tam}(2009)[60]$ & OR $(95 \% \mathrm{Cl})=1.57(1.23-2.00)$ per $1 \%$ increase \\
\hline & Kajiwara (2014) [76] & OR $(95 \% \mathrm{Cl})=1.21(1.08-1.36)$ per $1 \%$ increase \\
\hline & Stratton (2001) [51] & $\begin{array}{l}\text { Compared to } \mathrm{HbA} 1 \mathrm{C}<6.2 \%, \mathrm{OR}(95 \% \mathrm{Cl})=1.4(1.1-1.8) \text { for } \\
6.2-7.4 \% ; 2.5(2.0-3.2) \text { for }>7.4 \%\end{array}$ \\
\hline & Romero-Aroca (2011) [77] & OR $(95 \% \mathrm{Cl})=4.01(1.91-8.39)$ if $>7.0 \%$ vs. $\leq 7.0 \%$ \\
\hline & Tudor (1998) [53] & OR $(95 \% \mathrm{Cl})=1.50(0.96-2.36)$ per $2 \%$ increase \\
\hline & Kajiwara (2014) [76] & HR $(95 \% \mathrm{Cl})=1.33(1.18-1.51)$ per $1 \%$ increase \\
\hline & Janghorbani (2003) [212] & HR $(95 \% \mathrm{Cl})=1.08(1.007-1.15)$ per $1 \%$ increase \\
\hline & Salinero-Fort (2013) [59] & $\begin{array}{l}\text { Compared to } \mathrm{HbA} 1 \mathrm{C}<7 \% \mathrm{HR}(95 \% \mathrm{Cl})=1.39(1.01-1.92) \\
\text { for } 7-8 \% ; 1.90(1.30-2.77) \text { for }>8 \%\end{array}$ \\
\hline & Henricsson (2003) [111] & $\mathrm{HR}(95 \% \mathrm{Cl})=1.7(1.43-1.93)$ per $1 \%$ increase \\
\hline \multirow[t]{6}{*}{ Use of insulin/diabetes treatment } & Tudor (1998) [53] & $\begin{array}{l}\text { OR }(95 \% \mathrm{Cl})=2.00(0.75-5.35) \text { if on oral treatment vs. } \\
\text { no medications }\end{array}$ \\
\hline & & OR $(95 \% \mathrm{Cl})=9.30(2.69-32.16)$ if on insulin vs. no medications \\
\hline & Jones (2012) [52] & $\begin{array}{l}\text { Compared to diet control only, HR }(95 \% \mathrm{Cl})=1.77(1.44-2.17) \\
\text { if oral hypoglycemics only }\end{array}$ \\
\hline & & $\mathrm{HR}(95 \% \mathrm{Cl})=2.17(1.68-2.81)$ if using insulin \\
\hline & Thomas (2012) [49] & $\begin{array}{l}\text { Compared to diet control only, HR }(95 \% \mathrm{Cl})=1.41(1.36-1.47) \\
\text { if oral hypoglycemics only }\end{array}$ \\
\hline & & $\mathrm{HR}(95 \% \mathrm{Cl})=2.03(1.89-2.18)$ if using insulin \\
\hline \multirow[t]{5}{*}{ Blood pressure } & Jin (2014) [98] & $\begin{array}{l}\mathrm{OR}(95 \% \mathrm{Cl})=1.80(1.14-2.86) \text { if } \mathrm{SBP}>140 \mathrm{mmHg} \text { and/or } \\
\mathrm{DBP}>90 \mathrm{mmHg}\end{array}$ \\
\hline & Kajiwara (2014) [76] & OR $(95 \% \mathrm{Cl})=1.02(1.01-1.03)$ per $\mathrm{mmHg}$ increase in SBP \\
\hline & Stratton (2001) [51] & $\begin{array}{l}\text { Compared to }<125 \mathrm{mmHg} \text {, OR }(95 \% \mathrm{Cl})=1.5(1.2-2.6) \text { for } \\
\text { SBP was } 125-139 \mathrm{mmHg} ; 2.8(2.2-3.5) \text { if SBP was } \geq 140 \mathrm{mmHg}\end{array}$ \\
\hline & Romero-Aroca (2011) [77] & $\begin{array}{l}\mathrm{OR}(95 \% \mathrm{Cl})=3.31(1.62-6.75) \text { if } \mathrm{SBP}>140 \mathrm{mmHg} \\
\text { and/or } \mathrm{DBP}>90 \mathrm{mmHg}\end{array}$ \\
\hline & Tudor (1998) [53] & OR $(95 \% \mathrm{Cl})=1.81(1.02-3.20)$ per $20 \mathrm{mmHg}$ increase in SBP \\
\hline
\end{tabular}


Table 6 Incidence-derived risk factors for the development of diabetic retinopathy in cohort studies (Continued)

\begin{tabular}{|c|c|c|}
\hline & Kajiwara (2014) [76] & $\mathrm{HR}(95 \% \mathrm{Cl})=1.01(0.99-1.03)$ per $\mathrm{mmHg}$ increase in SBP \\
\hline & Jones (2012) [52] & $\mathrm{HR}(95 \% \mathrm{Cl})=0.72(0.64-0.81)$ if on anti-hypertensive medications \\
\hline \multirow[t]{3}{*}{ Obesity } & Kajiwara (2014) [76] & OR $(95 \% \mathrm{Cl})=1.07(1.01-1.13)$ per $\mathrm{kg} / \mathrm{m}^{2}$ increase in $\mathrm{BMl}$ \\
\hline & Kajiwara (2014) [76] & $\mathrm{HR}(95 \% \mathrm{Cl})=1.16(1.06-1.26)$ per $\mathrm{kg} / \mathrm{m}^{2}$ increase in $\mathrm{BMI}$ \\
\hline & Henricsson (2003) [111] & $\mathrm{HR}(95 \% \mathrm{Cl})=1.11(1.04-1.18)$ per $\mathrm{kg} / \mathrm{m}^{2}$ increase in $\mathrm{BMI}$ \\
\hline Nephropathy & Xu (2014) [75] & $\begin{array}{l}\mathrm{OR}(95 \% \mathrm{Cl})=1.01(1.002-1.022) \text { per } \mathrm{mmol} / \mathrm{L} \text { increase in } \\
\text { serum creatinine concentration }\end{array}$ \\
\hline Axial Length & Xu (2014) [75] & OR $(95 \% \mathrm{Cl})=0.48(0.33-0.71)$ per $\mathrm{mm}$ increase \\
\hline Cerebrospinal fluid pressure & Xu (2014) [75] & OR $(95 \% \mathrm{Cl})=1.10(1.01-1.21)$ per $\mathrm{mmHg}$ increase \\
\hline Fasting blood glucose & Janghorbani (2003) [212] & $\begin{array}{l}\mathrm{HR}(95 \% \mathrm{Cl})=1.003(1.0003-1.005) \text { per } \mathrm{mg} / \mathrm{dL} \text { increase in } \\
\text { fasting blood glucose }\end{array}$ \\
\hline Cholesterol & Salinero-Fort (2013) [59] & $\begin{array}{l}\text { Compared to }<100 \mathrm{mg} / \mathrm{dL} \text {, HR }(95 \% \mathrm{Cl})=0.87(0.65-1.16) \\
\text { for } \mathrm{LDL} 100-190 \mathrm{mg} / \mathrm{dL} ; 7.91(3.39-18.47) \text { for } \mathrm{LDL}>190 \mathrm{mg} / \mathrm{dL}\end{array}$ \\
\hline Aspirin use & Salinero-Fort (2013) [59] & $\mathrm{HR}(95 \% \mathrm{Cl})=1.65(1.22-2.24)$ if patient takes aspirin \\
\hline \multicolumn{3}{|l|}{ Risk factors for DME Incidence } \\
\hline Risk factor & Author (Year) & Strength of association \\
\hline Duration of diabetes & Romero-Aroca (2011) [77] & OR $(95 \% \mathrm{Cl})=8.921(4.321-26.773)$ if $>15$ years of diabetes duration \\
\hline $\mathrm{HbA} 1 \mathrm{c}$ & Romero-Aroca (2011) [77] & $\mathrm{OR}(95 \% \mathrm{Cl})=3.121(1.823-10.332)$ if $\mathrm{HbA} 1 \mathrm{c}$ is $>7.0 \%$ \\
\hline \multirow[t]{3}{*}{ Blood pressure } & Klein (2009) [73] & $\mathrm{HR}(95 \% \mathrm{Cl})=1.17(1.10-1.25)$ per $1 \%$ increase \\
\hline & Romero-Aroca (2011) [77] & $\begin{array}{l}\mathrm{OR}(95 \% \mathrm{Cl})=3.115(0.907-10.70) \text { if } \mathrm{SBP}>140 \mathrm{mmHg} \text { and/or } \\
\mathrm{DBP}>90 \mathrm{mmHg}\end{array}$ \\
\hline & Klein (2009) [73] & $\mathrm{HR}(95 \% \mathrm{Cl})=1.15(1.04-1.26)$ for every $10 \mathrm{mmHg}$ increase in SBP \\
\hline \multirow[t]{2}{*}{ Nephropathy } & Romero-Aroca (2011) [77] & $\begin{array}{l}\text { OR }(95 \% \mathrm{Cl})=6.774(3.442-18.236) \text { if protein excretion }>200 \mu \mathrm{g} / \mathrm{min} \\
\text { or }>300 \mu \mathrm{g} / \mathrm{mg} \text { of albumin: creatinine ratio }\end{array}$ \\
\hline & Klein (2009) [73] & $\mathrm{HR}(95 \% \mathrm{Cl})=1.43(0.99-2.08)$ if urine protein concentration $\geq 30 \mathrm{mg} / \mathrm{dL}$ \\
\hline Cholesterol & Romero-Aroca (2011) [77] & $\begin{array}{l}\mathrm{OR}(95 \% \mathrm{Cl})=4.125(1.125-15.857) \text { if Total cholesterol/HDL-cholesterol } \\
\text { ratio is }>3.5 \text { in men and }>3.0 \text { in women }\end{array}$ \\
\hline
\end{tabular}

OR odds ratio, $H R$ hazard ratios, $C l$ confidence interval, $L D L$ low density lipoprotein, $H D L$ high density lipoprotein, SBP systolic blood pressure, $D B P$ diastolic blood pressure

much more effective in preventing or delaying the onset of DR in patients with diabetes without DR, rather than limiting the severity of DR after it has occurred. In the case of DME, intensive glycemic control was associated with $46 \%$ reduction in the incidence of DME at the end of the trial and a $58 \%$ reduction 4 years later compared with those in the conventional group [89]. The burden of primary prevention of DR and DME hence falls heavily on primary care physicians, who are in the best position to achieve good glycemic control in patients who have not developed complications. In everyday clinical care however, it is difficult to replicate the intensity of glycemic control seen in these studies that were achieved under trial conditions. From the findings reported by the DCCT, intensive glycemic control actually increases risk of progression of existing DR in the first year of treatment [90]. However, this should not deter achieving tight glycemic control in patients with existing DR, as the long-term progression risk reduction outweighs that of the increased risk in the first year alone.
Glycemic control should be achieved early in the disease course and maintained for as long as possible, since its protective effect is sustained even if tight glycemic control is lost. This is the metabolic memory effect observed after the DCCT. Within a year after the end of DCCT, the glycemic control in the conventional group and intensive control group had converged, but the participants in the intensive control group still had lower prevalence of DR and DME than the participants in the conventional control group at 10 years after DCCT [91]. Risk reduction in the intensive control group was $52 \%$ between years 1 to 10 after DCCT, but dwindled to $12 \%$ between years 11 to 18 [92]. This implies that the metabolic memory effect fades with time, but this is confounded by improved glycemic control and risk reduction in the conventional control group since the end of DCCT. Besides implications for clinical treatment, metabolic memory also has implications on methodology of diabetes research, seeing that obtaining mean $\mathrm{HbA1c}$ of the entire course of diabetes may be needed to control for the effect of metabolic memory [93]. 
Apart from the absolute value of glycemia alone, the short-term variability of glycemia, such as spikes in postprandial glucose, is found to be associated with increased risk of microvascular complications [94]. However, there is insufficient data at this point to conclude that fluctuations in blood sugar levels is a causative factor in microvascular complications considering increased glycemic fluctuation can be due to a multitude of correlated factors that may all contribute to microvascular injury, such as severity of disease or poor compliance.

The benefits of achieving euglycemia should be balanced with the risk of hypoglycemia, especially in the elderly. In both the Action in Diabetes and Vascular Disease (ADVANCE) [95] and Action to Control Cardiovascular Risk in Diabetes (ACCORD) [96] trials, aggressive glycemic control (HbA1c $<6.5 \%)$ did not significantly reduce risk of retinopathy development or progression in type 2 diabetes. In ACCORD, it was found that such an aggressive manner of glycemic control may in fact be associated with increased mortality, but it was not ascertained whether this was directly due to metabolic complications of treatment, such as hypoglycemia. Current institution guidelines state that treatment goals of hyperglycemia are to be anywhere between $<6.5$ to $<7.5 \%$ of HbAlc. According to a recently published Cochrane review [97] however, there is no concrete evidence on any specific treatment target. Instead, the authors recommend that clinicians set individualized treatment goals based on age, disease progression, risk of hypoglycemic episodes, and psychological factors of the patient.

\section{Hypertension}

Multiple epidemiologic studies have identified hypertension as a risk factor for DR and DME [51, 53, 76, 77, 98]. In the UKPDS, tight blood pressure control (defined as target blood pressure $<150 / 85 \mathrm{mmHg}$ ) in patients with type 2 diabetes reduced the risk of microvascular disease by $37 \%$, the rate of progression of DR by $34 \%$, and the risk of deterioration of visual acuity by $47 \%$ [99]. Unlike in the case of hyperglycemia, the protective effect of blood pressure control waned quickly upon stopping intensive control [100]. Anti-hypertensive medications targeting the renin-angiotensin-aldosterone system (RAAS) are now the first line treatment for control of hypertension in patients with nephropathy as it was found that they had additional beneficial effects independent of their absolute hypotensive action. Since retinopathy and diabetic nephropathy are related microvascular complications, clinical trials such as the Diabetic Retinopathy Candesartan Trials (DIRECT) and Renin-Angiotensin System Study (RASS) measured the beneficial effects these classes of anti-hypertensive medications had on DR and DME. Candesartan was found to reduce the incidence of retinopathy by two or more steps in severity on the ETDRS scale by $18 \%$ or by three or more steps by $35 \%$ in type 1 diabetes, and increased regression of retinopathy by $34 \%$ in type 2 diabetes $[101,102]$. However, regression only occurred in mild $\mathrm{DR}$, and candesartan had no effect on incidence or progression of DME. In the RASS, enalapril and losartan reduced the risk of retinopathy progression by 65 and $70 \%$, respectively. Since it was observed that this effect was independent of blood pressure changes across the period of the trial, it was proposed that DR risk reduction was not mediated by an effect on hypertension.

A recently published Cochrane review concluded that intensive blood pressure control had a modest effect in reducing incidence of DR, but does not reduce risk of progression [103]. Insufficient evidence on adverse effects of strict blood pressure control in patients with diabetes made a cost-benefit analysis impossible in the review, and both clinicians and researchers should be aware of this gap in literature. Hence, the overall recommendation is to avoid intensive blood pressure control for the sole purpose of slowing DR progression. Instead, control of hypertension in a patient with diabetes should be focused on preventing or limiting progression of other vascular complications, particularly nephropathy, as well as lowering mortality. There is insufficient evidence for the use of RAS targeting anti-hypertensive medication specifically for preventing or treating retinopathy.

\section{Dyslipidemia}

As outlined in a previous review, the evidence for dyslipidemia as a risk factor for DR are inconsistent, and no single lipid measure had been consistently found to be associated with DR or DME [74]. In recent cohort studies, only the Madrid Diabetes Study found an association between low density lipoprotein (LDL) cholesterol and incidence of DR [59]. Moreover, a meta-analysis found that there was a dose-dependent relationship of statin use with increasing risk of diabetes [104]. It was then believed that statins might have effects on glucose homeostasis, such as decreasing insulin production or increasing insulin resistance, or both [105]. Therefore, while the use of statins is first-line treatment for dyslipidemia in the prevention of cardiovascular events in patients with diabetes, the evidence for intensive control by statins for the purposes of treating DR and DME are lacking.

Fenofibrate, a peroxisome proliferator-activated receptor alpha (PPAR $\alpha)$ agonist, has gathered interest on its effects on DR and DME. In an ancillary study of the Fenofibrate Intervention and Event-lowering in Diabetes (FIELD) cohort, participants treated with fenofibrate had a $31 \%$ reduced risk of requiring laser treatment for PDR or DME, compared to placebo [106]. However, 2-step progression of retinopathy did not differ significantly between the fenofibrate and placebo group, except for the subgroup with pre-existing DR. In this subgroup, risk of 2-step 
progression was almost a fifth of that compared to placebo. Moreover, in a more recent trial by the ACCORD group, adjunct fenofibrate with simvastatin compared to simvastatin alone reduced the rate of progression of DR (6.5 vs. $10.2 \%$, respectively) by at least 3 steps at 4 years [107]. Fenofibrate treatment may also have beneficial effects on DME, as it was found to have a moderate effect in decreasing macular volume in patients with DME [108]. The sample size of this study however, was relatively small, and more studies are required to study this association. Given the current evidence, it is found that patients with DR benefit most from fibrate therapy if they have hypertriglyceridemia and low serum high density lipoprotein (HDL)-cholesterol, and hence treatment can be justified in this subset of patients, with the hopes of slowing progression to PDR. However, generalization of fibrate treatment to all patients with diabetes at risk of DR is not recommended without stronger evidence [109].

\section{Obesity}

The effect obesity has on DR has been relatively wellstudied but with inconclusive and conflicting findings [110]. It may be possible that obesity has differing impacts on DR in type 1 diabetes as compared to type 2 diabetes. In the Diabetic Incidence Study in Sweden involving predominantly participants with type 1 diabetes, it was found that risk of developing DR increased by 1.11 (95 \% confidence interval (CI) 1.041.18) times per $\mathrm{kg} / \mathrm{m}^{2}$ increase in Body Mass Index (BMI) after 10 years of follow-up [111]. In the EURODIAB Prospective Complications Study, also involving patients with type 1 diabetes, larger waist to hip ratio was associated with incidence of DR after more than 7 years of follow-up [112].

In contrast, many studies in type 2 diabetes, performed primarily in Asia, found an inverse relationship between obesity and DR. In a cross-sectional study of the Shanghai Diabetes Registry Database, participants who were overweight had reduced risk of DR and VTDR [113]. A similar study on the multi-ethnic population in Singapore found the same risk reduction in obese patients for DR, VTDR and CSME [114].

The exact mechanisms underlying this discrepancy between type 1 and type 2 diabetes are not well understood. It was postulated that unintentional weight loss is a sign of advanced and severe type 2 diabetes, hence the observation of non-obese patients with type 2 diabetes being at higher risk of DR. In contrast, obesity and metabolic syndrome do not contribute to the etiology of type 1 diabetes, which is autoimmune in nature, and obese patients with type 1 diabetes may simply have more difficulties achieving good glycemic control. It should be noted that there are no prospective population-based studies in Asia on DR incidence, and the protective effect of obesity in
Asians with type 2 diabetesis yet to be confirmed by a cohort study.

Closely related to obesity is the study of obstructive sleep apnea (OSA) as a potential risk factor for DR and DME. A cross-sectional study in patients with type 2 diabetes found that OSA was associated with DR severity, but not DME [115]. A separate study on patients with CSME found high prevalence of sleep-disordered breathing in these patients, but severity of sleep-disordered breathing was not correlated with severity of DR or DME in this study [116]. However, the sample sizes of these studies were too small to draw any concrete conclusions.

Bariatric surgery is a highly effective treatment for morbid obesity that achieves glycemic control of diabetes rapidly. However, much like how intensive glucose control with medications or insulin increases risk of DR progression in the short-run, this rapid improvement in glycemic control post-bariatric surgery has been associated with progression of DR. Most studies presented in this area are case series, and a recent meta-analysis of these studies found that patients with pre-existing DR are 2.77 times (95 \% CI 1.10-6.99) more likely to have adverse outcomes in DR post-operatively than patients without pre-existing DR [117]. As mentioned earlier, increased risk of progression with intensive glycemic control occurred only in the first year of follow-up, with subsequent risk reduction with longer-term control [90]. It remains to be seen if this is the case with bariatric surgery as well, as no studies had sufficient follow-up time to determine if bariatric surgery has long-term benefits on DR.

\section{Novel risk factors}

\section{Inflammation}

Retinal and vitreous inflammation was observed in subjects with diabetes, both in animal models and human studies. The role of inflammation in DR and DME is therefore an area of extensive study, and has been reviewed previously [118]. As pointed out in the review however, current data suggests systemic inflammation cannot account for the characteristic lesions seen in DR and DME. Many conditions can lead to systemic inflammation (e.g. sepsis, autoimmune disease), but DR-like lesions and DME are not seen in these diseases. Hence, it seems that the local retinal inflammation seen in subjects with diabetes is not related to systemic inflammation. This challenges the validity of investigating systemic inflammatory markers such as serum C-reactive protein (CRP), interleukin-6 (IL-6) and tumor necrosis factor- $\alpha$ (TNF- $\alpha$ ) as risk factors for DR or DME. Indeed, inconsistencies in the association between systemic inflammatory markers and risk of DR and DME exist in the current literature. The EURODIAB Prospective Complications Study found an association between CRP, IL-6, TNF- $\alpha$ and presence of DR in subjects with type 1 diabetes via a cross-sectional 
study [119]. Other cross-sectional studies found no such association. The Multi-ethnic Study of Atherosclerosis did not find an association between CRP and DR or VTDR (which includes DME), but found an association between fibrinogen, an acute-phase reactant in systemic inflammation, and DR and VTDR [120]. The Singapore Malay Eye Study even found that raised CRP was associated with a lower prevalence of DR [121]. None of the studies found an association between systemic inflammatory markers and DME specifically.

Local retinal inflammation forms the basis of intravenous administration of corticosteroids. The Diabetic Retinopathy Clinical Research Network (DRCR.net) compared intravitreal triamcinolone versus focal/grid laser photocoagulation in patients with DME. The findings showed that the triamcinolone group had better visual acuity at the 4-month interval, but equivalent visual acuity at the 1-year interval. At the 2-year [122] and 3-year interval [123], mean visual acuity was better in the photocoagulation than the triamcinolone groups. Hence, corticosteroid treatment for DME is effective, but the effect is transient. Clinicians also have to be cautious with adverse effects such as elevated intraocular pressure and cataract formation.

Vascular endothelial growth factor (VEGF) is a key modulator of angiogenesis and vascular permeability, and is upregulated by inflammatory cytokines [124]. AntiVEGF agents have been used successfully for the treatment of both PDR and DME $[125,126]$. Ranibizumab, an anti-VEGF agent, was more effective than laser therapy in restoring vision for DME [127], although just like with corticosteroids, ranibizumab is associated with elevations in intraocular pressure [128]. In recent reports, the DRCR.net compared outcomes in DME treated by aflibercept, bevacizumab or ranibizumab, and found that aflibercept provided superior visual recovery if baseline visual acuity was poorer than 69 ETDRS letters (approximately $6 / 15$ Snellen) when compared to the other anti-VEGF agents, but there was no significant difference between aflibercept and the other anti-VEGF agents if baseline visual acuity was better than 69 letters [129].

Anti-VEGF agents appear superior to corticosteroids in terms of efficacy. DRCR.net compared ranibizumab and concurrent photocoagulation against triamcinolone with photocoagulation in patients with DME, and found that ranibizumab achieved better visual outcome at 1-year follow-up than triamcinolone, except in a subset of patients with pseudophakic eyes [130]. In this subset of participants, triamcinolone achieved comparable visual outcome when compared with ranibizumab, possibly because of the removed effect of steroid-induced cataract formation in pseudophakic eyes. Consistent results were obtained at 2-year follow-up [131].

\section{Metabolic hormones}

Hormones involved in metabolism have been hypothesized to play key roles in the pathogenesis of microvascular complications in diabetes, due to their roles in both metabolic and inflammatory pathways [132]. In particular, leptin and adiponectin, which are actively secreted by adipocytes to regulate energy balance in the body, have been implicated as potential risk factors.

Leptin may play a role in inciting inflammation. Leptin was found to cause upregulation of VEGF in retinal pericytes [133], hence stimulating angiogenesis in the ischemic retina [134], and possibly contributing to the neovascularization seen in PDR. Elevated serum and vitreous leptin was observed in patients with diabetes, and vitreous leptin was especially elevated in patients with PDR [135]. However, cross-sectional studies could not find an association between elevated serum leptin and DR [136, 137], though it should be noted that the sample sizes of these studies were relatively small and they may be underpowered.

Adiponectin has been found to induce dilation of retinal arterioles via upregulation of endothelial cell nitric oxide production, in animal studies [138]. Studies by the same group in human subjects with mild DR found that serum adiponectin was positively correlated with retinal blood flow velocity and negatively correlated with retinal arterial resistance [139]. Hence, adiponectin may have a role in countering ischemia by promoting reperfusion in the ischemic retina. In vitro studies also found that it downregulates VEGF and thus may have anti-angiogenic properties [140]. Large population-based cross-sectional studies found that elevated serum adiponectin in patients with DR correlated with severity of DR when compared to patients without DR $[141,142]$. However, there are inconsistencies in literature, with one study finding decreased serum adiponectin in participants with PDR [143]. Given that basic science suggests adiponectin as mainly protective against the development of microvascular complications, the observation that serum adiponectin is elevated in patients with severe DR appears contradictory. It may be that upregulation of adiponectin secretion can be attributed to a natural response that ameliorates the effects of severe microvascular disease, but prospective cohort studies are needed to establish the temporal link between adiponectin levels and the development and progression of DR. Overall, it appears research in adiponectin has produced more promising and consistent results than leptin. The association between these hormones and DME has yet to be studied.

\section{Oxidative stress}

Oxidative stress is the accumulation of free radicals in the form of reactive oxygen species (ROS). Highly efficient physiological mechanisms consisting of endogenous free 
radical scavengers usually keep oxidative stress low. However, under pathological conditions, ROS production may be increased such that the defensive mechanisms are overwhelmed, or the protective mechanisms themselves may be impaired, or both [144]. Oxidative stress has been linked to the histopathological changes of DR, such as retinal basement membrane thickening [145] and capillary cell loss [146]. Increased ROS and decreased antioxidant potential has also been found in patients with diabetes, especially if they have DR [147]. The effects of oxidative stress are observed early in the course of diabetes, and its effects on microvasculature persist even if hyperglycemia is subsequently corrected. Hence, oxidative stress is likely to be the mechanism behind the "metabolic memory" effect mentioned earlier, where sustained periods of hyperglycemia early in the disease course has long-lasting effects on future microvascular complications [148].

Multiple biochemical pathways involved in DR pathogenesis are linked to oxidative stress. The accumulation of advanced glycation end products (AGE) in retinal pericytes upregulates cellular expression of its receptor (RAGE). AGE-RAGE overexpression produces ROS, activating apoptotic pathways to cause pericyte loss, seen in early DR [149] The polyol pathway is augmented in hyperglycemic conditions, resulting in overconsumption of NADPH, reducing its availability for formation of the key endogenous antioxidant glutathione [150]. ROS has also been found to increase the activity of protein kinase $\mathrm{C}$ (PKC), a family of serine-threonine kinases that cause vascular dysfunction by increasing permeability, altering blood flow, and stimulating neovascularization. Vascular dysfunction and neovascularization is potentiated further as PKC induces VEGF [144]. Due to how multiple pathways activate and can be activated by oxidative stress, therapeutic strategies targeting any single pathway is unlikely to be effective, as shown in the multiple randomized-controlled trials [151-153]. Research has since focused on mitochondrial dysfunction as the main upstream source of oxidative stress, but whether research in this area will yield novel treatment strategies remains to be seen [148].

From an epidemiologic standpoint, given the importance of oxidative stress in the pathogenesis of DR, reliable and accessible markers of oxidative stress are valuable measures of disease severity and prognosis. To date, most studies relating oxidative stress to DR involve in vitro and animal studies, and oxidative stress markers have not been investigated in large epidemiologic studies. Small crosssectional studies have consistently found elevated markers of oxidative stress such as lipid peroxide (LPO) and malondialdehyde in both vitreous and serum of human subjects with DR $[154,155]$. In particular, serum LPO was found to correlate highly with vitreous LPO, and that LPO correlated well with key disease mediators such as VEGF, suggesting that serum LPO may be a suitable proxy measure of DR severity [154]. More studies will be needed to confirm this association.

\section{Vitamin D}

On top of its well-known effects on calcium metabolism, Vitamin $\mathrm{D}$ has anti-angiogenic and anti-inflammatory effects that have implicated Vitamin D deficiency in the pathogenesis of various types of pathology, such as malignancy, autoimmune disease, cardiovascular disease and diabetes [156].

It is thus intuitive that Vitamin D has a protective effect on DR and DME, since anti-angiogenesis may slow progression to PDR and anti-inflammatory properties may counteract development of both DR and DME. Calcitriol, or 1,25-dihydroxycholecalciferol, is the metabolically active form of Vitamin D, and has been found to be a potent inhibitor of retinal neovascularization in vitro [157], possibly through suppressing TGF- $\beta$ and VEGF levels [158]. Epidemiologic studies have found vitamin $\mathrm{D}$ deficiency to be associated with increased prevalence and severity of diabetic retinopathy, in both type $1[159,160]$ and type 2 diabetes [161-163]. However, all these studies are cross-sectional. No data is available on how Vitamin D influences prevalence of DME.

\section{Genetic factors}

As highlighted earlier in this review, certain trends in DR prevalence and incidence cannot be explained by environmental or socioeconomic factors, such as the abnormally high prevalence of DR in rural China, or the large proportion of VTDR in the Middle East. Some patients appear predisposed to severe DR even with adequate risk factor control, while others avoided DR despite poor control and long diabetes duration [164]. Familial aggregation studies and clinical trials including the DCCT have demonstrated a heritable tendency for severe retinopathy in type 1 and type 2 diabetes, independent of shared risk factors [165-168]. Hence, the hypothesis of differential genetic susceptibility to DR has drawn interest. The list of polymorphisms reviewed here is not exhaustive, but focuses on genes affecting the biological pathways mentioned earlier in the review.

Polymorphisms in the adipose most abundant gene transcript-1 (apM-1) gene on chromosome 1q21.3-q23 that codes for adiponectin have been detected to influence serum adiponectin levels and risk of DR [142]. Participants with type 2 diabetes heterozygous for the Tyr111His polymorphism at exon 3 (Tyr/His) had significantly higher serum adiponectin levels than participants who were homozygous for Tyr111His (Tyr/Tyr), but this had no statistically significant effect on the risk of DR. Participants with type 2 diabetes who had the mutant +45 TG allele at 
the Gly15Gly polymorphism had no observable differences in serum adiponectin levels when compared to participants with the wild type $+45 \mathrm{TT}$ allele, but they had a significantly lower risk of DR. It was unclear why the reduced risk of DR in this study appeared independent of serum adiponectin levels. Multiple VEGF polymorphisms have been investigated for their link to DR. The $-2578 \mathrm{C} /$ $\mathrm{A},+936 \mathrm{C} / \mathrm{T}$ and $-460 \mathrm{~T} / \mathrm{C}$ polymorphisms of VEGF have been associated with DR in Asians by meta-analysis of cross-sectional studies [169, 170]; The C-634G polymorphism was linked to risk of DME. The CC genotype of this polymorphism was associated with the presence of DME, but was also associated with better treatment response to bevacizumab when compared to the CG and GG genotypes [171]. Recently, single nucleotide polymorphisms in the VEGF-C gene have been associated with DR and DME in both type 1 and type 2 diabetes [172].

Aldose reductase is the rate-limiting enzyme in the polyol pathway that contributes to oxidative stress in patients with diabetes. The $C(-106) \mathrm{T}$ polymorphism was found on meta-analysis to be associated with risk of DR in type 1, but not type 2 diabetes [173]. Genes coding for enzymes in antioxidant pathways such as catalase, superoxide dismutase and glutathione peroxidase are downregulated in patients with DR compared to patients with diabetes but without DR, but it is unknown if certain polymorphisms predispose to this observation [174]. Vitamin D receptor gene polymorphisms may also predispose to DR. T to C substitution at the Taq I site of the Vitamin D receptor gene [175], and $T$ to $C$ substitution at the start codon FokI [176], was associated with severe DR in patients with type 1 diabetes.

A few genome-wide studies have identified novel gene loci associated with DR [177-180]. Association of novel genes related to vascular endothelium proliferation and capillary permeability, such as PLXDC2 and ARHGAP22, imply that our understanding of angiogenic and inflammatory pathways is still incomplete [178]. Interestingly, polymorphism of RP1-90 L14.1, a long intergenic noncoding RNA gene adjacent to CEP162 was found to be associated with susceptibility to DR [180]. Since CEP162 is a key protein in cell ciliogenesis [181], it raises the question if dysregulation of ciliary assembly plays a role in DR pathogenesis.

\section{Epidemiology of diabetes-related vision loss}

While treatment options such as pan-retinal laser photocoagulation can largely control neovascularization and prevent blindness, these treatments cannot restore vision, and in fact have vision-impairing effects of their own. Intravitreal agents such as anti-vascular endothelial growth factor (VEGF) agents do not fully restore vision in all patients, and require frequent and costly doses for effective treatment. Vision loss from DR or DME is hence a significant healthcare burden [1].

A recent systematic review estimated that in 2010, 3.63 million people worldwide suffer from moderate and severe vision loss due to DR and its related sequelae, defined as visual acuity in the better eye being worse than Snellen 6/18 but at least 3/60. An estimated 850 thousand more people suffer from DR-related blindness, defined as visual acuity worse than $3 / 60$ in the better eye [2]. Prevalence of vision impairment and blindness due to DR was found to be on the uptrend, even though total prevalence of vision impairment and blindness was decreasing. Findings from reviews of cross-sectional studies in Europe [182], South-East Asia and Oceania [183], consistently found DR to be the fifth most common cause of moderate and severe vision loss and blindness, behind causes such as uncorrected refractive error, cataracts, macular degeneration and glaucoma. In Africa, DR is the sixth most common cause of visual impairment and blindness, behind the above-listed conditions and trachoma [184]. In the USA, the WESDR investigated visual impairment in patients with type 1 diabetes, and found that 25-year cumulative incidence of visual impairment (defined as poorer than $6 / 12$ best-corrected visual acuity in the better eye) and severe visual impairment (defined as poorer than 6/60 best-corrected visual acuity in the better eye) to be 13 and $3 \%$, respectively [185].

Recent data in Leeds, UK, found that in 2008 to 2010, DR accounted for $6.1-8.3 \%$ of visual impairment certification. Extrapolated to the total population of the metropolitan area in Leeds, this estimates that 30.0 to 43.2 people per million per year will become severely visually impaired due to DR and its sequelae [186]. In Fife, Scotland, between 2000 and 2009, the mean incidence of blindness (defined as above) was 13.8 per million per year for the total population of the county [187]. In the Sankara Nethralaya Diabetic Retinopathy Epidemiology and Molecular Genetics Study (SNDREAMS) in type 2 diabetes, the prevalence of visual impairment and blindness was 4 and $0.1 \%$, respectively [188].

\section{Other eye complications of diabetes}

While DR and DME are the most important and wellstudied diabetes-related eye complication, many patients with diabetes are at risk of vision loss from other diabetes-related eye conditions that range from mild vision impairment to blindness. Diabetes is associated with early and rapid development of cataracts, and is hence a major cause of visual impairment among patients with diabetes. The Singapore Malay Eye Study (SiMES) found patients with diabetes to be more likely to have cortical and posterior subcapsular cataracts [189]. In the WESDR 
study and SN-DREAMS study, presence of cataracts were significant factors contributing to visual impairment and blindness in patients with diabetes $[185,188]$. Many patients with diabetes require cataract surgery at a relatively younger age. In the WESDR, 10-year cumulative incidence of cataract surgery was $8 \%$ in patients with type 1 diabetes and $25 \%$ in patients with type 2 diabetes [190]. While usually a surgical procedure with good outcomes, cataract surgery is complicated in patients with diabetes as they may develop DME after surgery [191].

Although findings have been inconsistent, diabetes has been found to be a risk factor for developing primary glaucoma in some population-based studies [192]. For instance, SiMES found an association between ocular hypertension and diabetes, but not glaucoma [189]. Neovascular glaucoma, which is both a blinding and painful condition, can also arise from PDR. A recent report found that $7.1 \%$ of patients with PDR requiring vitrectomy developed neovascular glaucoma 1 year after surgery [193]. Epiretinal membranes, which can cause significant visual impairment, were also found to be more common among patients with diabetes that have undergone cataract surgery [189].

\section{Relationship of DR and DME with diabetes related systemic complications \\ Microvascular complications}

Diabetic nephropathy is closely associated to DR and DME, as many of the pathologic processes affecting microvasculature in DR are likely to be causative of diabetic nephropathy as well. In a cross-sectional study in Korea, compared to patients without DR, patients with DR had 2.11 the odds ( $95 \%$ CI 1.04-4.26) of having overt diabetic nephropathy, defined as protein excretion of more than $300 \mathrm{mg}$ per $24 \mathrm{~h}$ or albumin/creatinine ratio greater than $300 \mu \mathrm{g} / \mathrm{mg}$ [194]. Ischemic diabetic retinopathy, as evidenced by capillary non-perfusion found on fundal fluorescein angiogram, was found to be associated with progression of diabetic nephropathy. Patients with more than or equal to 10 optic disc areas of capillary nonperfusion had 6.64 times the risk of progression of nephropathy [195]. Increasing severity of DR was associated with increasing severity of chronic kidney disease and decreased estimated glomerular filtration rate [196]. In a 15-year follow-up study, development of overt nephropathy (defined as above) was found to be associated with the development of DME [197]. Few studies related the development of neuropathy with DR. However, the SNDREAMS found an association between neuropathy and visual-impairment in patients with diabetes [188].

\section{Macrovascular complications}

The strength of association between DR and macrovascular complications, such as cardiovascular disease is just as strong as in nephropathy [8]. In the Chennai Urban Rural Epidemiology Study, prevalence of coronary heart disease was higher among patients with DR as compared to those without DR [198]. An eight-year cohort study in Japan found that patients who developed signs of mild DR were already at higher risk of coronary heart disease or stroke [9]. Factoring presence of DR in the assessment of patients with diabetes also improved risk assessment of silent myocardial infarcts [199]. Presence of DR was also associated with mortality from cardiovascular disease, especially if there is concomitant nephropathy [200]. Literature relating DR with peripheral vascular disease is sparse, but a recent cross-sectional study in China found an association between presence of PDR with lower ankle-brachial index and lower toe-brachial index [201].

\section{Conclusions}

As this review shows, the epidemiology of DR has been extensively studied. The use of a common grading system, the ETDRS severity scale and its modifications, has facilitated standardized diagnosis and severity classification of DR in multiple epidemiologic studies, allowing comparisons of prevalence, incidence, progression and regression of DR. Review of literature published within the past five years consistently found higher DR prevalence in Western countries compared to Middle-East and Asian countries. Notable exceptions include Saudi Arabia and Singapore, two of the most affluent countries in Asia, where DR prevalence is comparable to that observed in the US and UK.

Given the increasing affluence of developing economies such as China and India, the healthcare burden of DR can be expected to be on the uptrend in the decades ahead. More recently, cross-sectional studies from developing countries are being published. Understandably, the sample sizes of these studies tend to be small, and few are population-based. However, it is clear that while people in developing countries are at lower risk of developing diabetes, they have an equivalent if not higher risk of developing DR upon onset of diabetes. While traditional causes of visual impairment and blindness in developing countries such as cataracts and trachoma are declining, the prevalence of DR is growing. Gaps in the literature on the epidemiology of DR include the lack of populationbased cohort studies investigating the incidence, progression, and regression in Asian and developing-world populations.

In contrast to DR, the epidemiology of DME is much less well studied. Existing studies are split between the use of two diagnostic criteria, one for DME and the other for CSME. Since the CSME criteria are substantially stricter than the DME criteria, direct comparisons between these studies cannot be made. The lack of a severity scale also precludes the study of progression and regression of DME. The diagnosis of DME itself is more challenging 
than DR. While DR can be diagnosed and classified adequately with the assessment of non-stereoscopic fundus photos, the diagnosis of DME using this same modality is challenging as macular thickening is difficult to assess in non-stereoscopic photographs. There is no consensus on OCT-based severity classification for DME. More research will have to be carried out to overcome these hurdles in diagnosis and classification of DME.

The investigation of risk factors has also revealed interesting considerations both in clinical practice and research. Hyperglycemia remains the most important modifiable risk factor for DR, and intensive glycemic control has been proven to have potent and long-lasting protective effects against development and progression of DR and DME. As the evidence behind hypertension and dyslipidemia as risk factors is weaker than in hyperglycemia, intensive control of hypertension and dyslipidemia should not be sought solely on the basis to prevent onset or progression of DR and DME, but taken in consideration of other complications (e.g. reduction in nephropathy and cardiovascular diseases).

Among novel risk factors, increased serum adiponectin and LPO were found to be associated with greater prevalence of DR. Vitamin D deficiency has also been found to be associated with DR, but more evidence is needed to ascertain efficacy of Vitamin D supplementation in the prevention of DR. These novel risk factors are promising, but the findings that have been made in cross-sectional studies have to be supported by consistent findings in prospective cohort studies. The relationship between these factors and DME is unknown and is worth exploring.

The association between DR and other vascular diseases are important areas of study. DR is strongly associated with nephropathy, which has significant burden on healthcare systems due to the need for renal replacement therapy. The presence of DR is also associated with vascular diseases that are disabling, such as stroke and peripheral vascular disease, or life threatening, such as myocardial infarction. Physicians and ophthalmologists should therefore be aware that patients with DR and DME are receiving appropriate assessment and treatment for these comorbidities.

\footnotetext{
Abbreviations

ACCORD: Action to control cardiovascular risk in diabetes; ADVANCE: Action in diabetes and vascular disease; AGE: Advanced glycation end products; apM-1: Adipose most abundant gene transcript-1; CRP: C-reactive protein; CSME: Clinically significant macular edema; DCCT: Diabetes control and complications trial; DCPD1987: Danish cohort of pediatric diabetes 1987; DIRECT: Diabetic retinopathy candesartan trials; DME: Diabetic macular edema; DR: Diabetic retinopathy; DRCR.net: Diabetic retinopathy clinical research network; ETDRS: Early Treatment for diabetic retinopathy study; FIELD: Fenofibrate intervention and event-lowering in diabetes:

IL-6: Interleukin-6; OCT: Optical coherence tomography; OSA: Obstructive sleep apnea; PDR: Proliferative diabetic retinopathy; PPARa: Peroxisome proliferator-activated receptor alpha; PKC: Protein kinase C; RAAS: Reninangiotensin-aldosterone system; RAGE: Receptor of advanced glycation end products; RASS: Renin-Angiotensin System Study; ROS: Reactive oxygen
}

species; SiMES: Singapore Malay Eye Study; SN-DREAMS: Sankara Nethralaya Diabetic Retinopathy Epidemiology and Molecular Genetics Study; TGF$\beta$ : Transforming growth factor beta; TNF-a: Tumor necrosis factor-a; UK: United Kingdom; UKPDS: United Kingdom prospective diabetes study; USA: United States of America; VEGF: Vascular endothelial growth factor; VTDR: Vision-threatening diabetic retinopathy; WESDR: Wisconsin epidemiologic study of diabetic retinopathy.

\section{Competing interests}

The authors declare that they have no competing interests.

\section{Authors' contributions}

$\mathrm{RL}$ performed the literature review and drafted the manuscript. CS was involved in drafting the manuscript and critically revising it. WTY critically revised the manuscript and gave final approval of the version to be published. All authors read and approved the final manuscript.

\section{Author details}

${ }^{1}$ Singapore Eye Research Institute, Singapore National Eye Centre, Singapore, Singapore. ${ }^{2}$ Yong Loo Lin School of Medicine, National University of Singapore, Singapore, Singapore. ${ }^{3}$ Ophthalmology and Visual Sciences Academic Clinical Program, Duke-NUS Graduate Medical School, Singapore, Singapore.

Received: 11 August 2015 Accepted: 1 September 2015

Published online: 30 September 2015

\section{References}

1. Cheung N, Mitchell P, Wong TY. Diabetic retinopathy. Lancet. 2010;376(9735):124-36.

2. Bourne RR, Stevens GA, White RA, Smith $J$, Flaxman SR, Price $H$, et al. Causes of vision loss worldwide, 1990-2010: a systematic analysis. Lancet Glob Health. 2013;1(6):e339-49.

3. Yau JW, Rogers SL, Kawasaki R, Lamoureux EL, Kowalski JW, Bek T, et al, Global prevalence and major risk factors of diabetic retinopathy. Diabetes Care. 2012;35(3):556-64.

4. Lightman S, Towler HM. Diabetic retinopathy. Clin Cornerstone. 2003;5(2):12-21.

5. Tong L, Vernon SA, Kiel W, Sung V, Orr GM. Association of macular involvement with proliferative retinopathy in type 2 diabetes. Diabet Med. 2001;18(5):388-94.

6. He F, Xia X, Wu XF, Yu XQ, Huang FX. Diabetic retinopathy in predicting diabetic nephropathy in patients with type 2 diabetes and renal disease: a meta-analysis. Diabetologia. 2013;56(3):457-66.

7. Hagg S, Thorn LM, Putaala J, Liebkind R, Harjutsalo V, Forsblom CM, et al. Incidence of stroke according to presence of diabetic nephropathy and severe diabetic retinopathy in patients with type 1 diabetes. Diabetes Care. 2013;36(12):4140-6.

8. Mottl AK, Pajewski N, Fonseca V, Ismail-Beigi F, Chew E, Ambrosius WT, et al. The degree of retinopathy is equally predictive for renal and macrovascular outcomes in the ACCORD Trial. J Diabetes Complications. 2014;28(6):874-9.

9. Kawasaki R, Tanaka S, Tanaka S, Abe S, Sone H, Yokote K, et al. Risk of cardiovascular diseases is increased even with mild diabetic retinopathy: the Japan Diabetes Complications Study. Ophthalmology. 2013;120(3):574-82.

10. Thomas RL, Dunstan FD, Luzio SD, Chowdhury SR, North RV, Hale SL, et al. Prevalence of diabetic retinopathy within a national diabetic retinopathy screening service. Br J Ophthalmol. 2015;99(1):64-8.

11. Pedro RA, Ramon SA, Marc BB, Juan FB, Isabel MM. Prevalence and relationship between diabetic retinopathy and nephropathy, and its risk factors in the North-East of Spain, a population-based study. Ophthalmic Epidemiol. 2010;17(4):251-65.

12. Hautala N, Hannula V, Palosaari T, Ebeling T, Falck A. Prevalence of diabetic retinopathy in young adults with type 1 diabetes since childhood: the Oulu cohort study of diabetic retinopathy. Acta Ophthalmol. 2014;92(8):749-52.

13. Bertelsen $G$, Peto $T$, Lindekleiv $H$, Schirmer $H$, Solbu MD, Toft I, et al. Tromso eye study: prevalence and risk factors of diabetic retinopathy. Acta Ophthalmol. 2013:91(8):716-21.

14. Knudsen LL, Lervang HH, Lundbye-Christensen S, Gorst-Rasmussen A. The north Jutland county diabetic retinopathy study: population characteristics. Br J Ophthalmol. 2006;90(11):1404-9. 
15. Dedov I, Maslova O, Suntsov Y, Bolotskaia L, Milenkaia T, Besmertnaia L. Prevalence of diabetic retinopathy and cataract in adult patients with type 1 and type 2 diabetes in Russia. Rev Diabet Stud. 2009;6(2):124-9.

16. Roy MS, Klein R, O'Colmain BJ, Klein BE, Moss SE, Kempen JH. The prevalence of diabetic retinopathy among adult type 1 diabetic persons in the United States. Arch Ophthalmol. 2004;122(4):546-51.

17. Kempen $\mathrm{JH}, \mathrm{O}^{\prime}$ Colmain BJ, Leske MC, Haffner SM, Klein R, Moss SE, et al. The prevalence of diabetic retinopathy among adults in the United States. Arch Ophthalmol. 2004;122(4):552-63.

18. Zhang X, Saaddine JB, Chou CF, Cotch MF, Cheng YJ, Geiss LS, et al. Prevalence of diabetic retinopathy in the United States, 2005-2008. JAMA. 2010;304(6):649-56.

19. Kung K, Chow KM, Hui EM, Leung M, Leung SY, Szeto CC, et al. Prevalence of complications among Chinese diabetic patients in urban primary care clinics: a cross-sectional study. BMC Fam Pract. 2014;15:8.

20. Jee D, Lee WK, Kang S. Prevalence and risk factors for diabetic retinopathy: the Korea National Health and Nutrition Examination Survey 2008-2011. Invest Ophthalmol Vis Sci. 2013;54(10):6827-33.

21. Raman R, Rani PK, Reddi Rachepalle S, Gnanamoorthy P, Uthra S, Kumaramanickavel G, et al. Prevalence of diabetic retinopathy in India: Sankara Nethralaya diabetic retinopathy epidemiology and molecular genetics study report 2. Ophthalmology. 2009;116(2):311-8.

22. Liu L, Wu X, Liu L, Geng J, Yuan Z, Shan Z, et al. Prevalence of diabetic retinopathy in mainland China: a meta-analysis. PLoS One. 2012;7(9):e45264.

23. Huang OS, Tay WT, Ong PG, Sabanayagam C, Cheng CY, Tan GS, et al. Prevalence and determinants of undiagnosed diabetic retinopathy and vision-threatening retinopathy in a multiethnic Asian cohort: the Singapore Epidemiology of Eye Diseases (SEED) study. Br J Ophthalmol. 2015

24. Zheng Y, Lamoureux EL, Lavanya R, Wu R, Ikram MK, Wang JJ, et al. Prevalence and risk factors of diabetic retinopathy in migrant Indians in an urbanized society in Asia: the Singapore Indian eye study. Ophthalmology. 2012;119(10):2119-24.

25. Rema M, Premkumar S, Anitha B, Deepa R, Pradeepa R, Mohan V. Prevalence of diabetic retinopathy in urban India: the Chennai Urban Rural Epidemiology Study (CURES) eye study, I. Invest Ophthalmol Vis Sci. 2005;46(7):2328-33.

26. Al Ghamdi AH, Rabiu M, Hajar S, Yorston D, Kuper H, Polack S. Rapid assessment of avoidable blindness and diabetic retinopathy in Taif, Saudi Arabia. Br J Ophthalmol. 2012;96(9):1168-72.

27. Papakonstantinou E, Tsinopoulos I, Dimitrakos S, Dehghan MH, Katibeh M, Ahmadieh $\mathrm{H}$, et al. Prevalence and risk factors for diabetic retinopathy in the 40 to 80 year-old population in Yazd, Iran: the Yazd Eye Study. J Diabetes. 2015;7(1):139-41.

28. Wang FH, Liang YB, Zhang F, Wang JJ, Wei WB, Tao QS, et al. Prevalence of diabetic retinopathy in rural China: the Handan Eye Study. Ophthalmology. 2009;116(3):461-7.

29. Raman R, Ganesan S, Pal SS, Kulothungan V, Sharma T. Prevalence and risk factors for diabetic retinopathy in rural India. Sankara Nethralaya Diabetic Retinopathy Epidemiology and Molecular Genetic Study III (SN-DREAMS III), report no 2. BMJ Open Diabetes Res Care. 2014;2(1):e000005.

30. Katulanda $P$, Waniganayake $Y C$, Ranasinghe $P$, Wijetunga WU, Jayaweera $M$, Wijesinghe NP, et al. Retinopathy among young adults with diabetes mellitus from a tertiary care setting in Sri Lanka. BMC Endocr Disord. 2014;14:20.

31. Akhter A, Fatema K, Ahmed SF, Afroz A, Ali L, Hussain A. Prevalence and associated risk indicators of retinopathy in a rural Bangladeshi population with and without diabetes. Ophthalmic Epidemiol. 2013;20(4):220-7.

32. Thapa R, Joshi DM, Rizyal A, Maharjan N, Joshi RD. Prevalence, risk factors and awareness of diabetic retinopathy among admitted diabetic patients at a tertiary level hospital in Kathmandu. Nepal J Ophthalmol. 2014;6(11) doi:10.3126/nepjoph.v6i1.10760

33. Kahloun R, Jelliti B, Zaouali S, Attia S, Ben Yahia S, Resnikoff S, et al. Prevalence and causes of visual impairment in diabetic patients in Tunisia, North Africa. Eye (Lond). 2014;28(8):986-91.

34. Mathenge W, Bastawrous A, Peto T, Leung I, Yorston D, Foster A, et al. Prevalence and correlates of diabetic retinopathy in a population-based survey of older people in Nakuru, Kenya. Ophthalmic Epidemiol. 2014;21(3):169-77.
35. Sharew G, llako DR, Kimani K, Gelaw Y. Prevalence of diabetic retinopathy in Jimma University Hospital, Southwest Ethiopia. Ethiop Med J. 2013;51(2):105-13.

36. Raman R, Gupta A, Krishna S, Kulothungan V, Sharma T. Prevalence and risk factors for diabetic microvascular complications in newly diagnosed type II diabetes mellitus. Sankara Nethralaya Diabetic Retinopathy Epidemiology and Molecular Genetic Study (SN-DREAMS, report 27). J Diabetes Complications. 2012;26(2):123-8.

37. Kostev K, Rathmann W. Diabetic retinopathy at diagnosis of type 2 diabetes in the UK: a database analysis. Diabetologia. 2013;56(1):109-11.

38. Tapp RJ, Shaw JE, Harper CA, de Courten MP, Balkau B, McCarty DJ, et al. The prevalence of and factors associated with diabetic retinopathy in the Australian population. Diabetes Care. 2003;26(6):1731-7.

39. Wong TY, Cheung N, Tay WT, Wang JJ, Aung T, Saw SM, et al. Prevalence and risk factors for diabetic retinopathy: the Singapore Malay Eye Study. Ophthalmology. 2008;115(11):1869-75.

40. Looker HC, Nyangoma SO, Cromie D, Olson JA, Leese GP, Black M, et al. Diabetic retinopathy at diagnosis of type 2 diabetes in Scotland. Diabetologia. 2012;55(9):2335-42.

41. Klein R, Klein BK, Moss SE, Davis MD, DeMets DL. The wisconsin epidemiologic study of diabetic retinopathy: Ix. four-year incidence and progression of diabetic retinopathy when age at diagnosis is less than 30 years. Arch Ophthalmol. 1989;107(2):237-43.

42. Klein R, Klein BE, Moss SE, Cruickshanks KJ. The Wisconsin Epidemiologic Study of diabetic retinopathy. XIV. Ten-year incidence and progression of diabetic retinopathy. Arch Ophthalmol. 1994;112(9):1217-28.

43. Klein R, Klein BE, Moss SE, Cruickshanks KJ. The Wisconsin Epidemiologic Study of Diabetic Retinopathy: XVII. The 14-year incidence and progression of diabetic retinopathy and associated risk factors in type 1 diabetes. Ophthalmology. 1998;105(10):1801-15.

44. Klein R, Knudtson MD, Lee KE, Gangnon R, Klein BE. The Wisconsin Epidemiologic Study of Diabetic Retinopathy: XXII the twenty-five-year progression of retinopathy in persons with type 1 diabetes. Ophthalmology. 2008;115(11):1859-68.

45. Broe R, Rasmussen ML, Frydkjaer-Olsen U, Olsen BS, Mortensen HB, Peto T, et al. The 16-year incidence, progression and regression of diabetic retinopathy in a young population-based Danish cohort with type 1 diabetes mellitus: The Danish cohort of pediatric diabetes 1987 (DCPD1987). Acta Diabetol. 2014;51(3):413-20.

46. Younis N, Broadbent DM, Harding SP, Vora JP. Incidence of sightthreatening retinopathy in type 1 diabetes in a systematic screening programme. Diabet Med. 2003;20(9):758-65.

47. Martin-Merino E, Fortuny J, Rivero-Ferrer E, Garcia-Rodriguez LA. Incidence of retinal complications in a cohort of newly diagnosed diabetic patients. PLoS One. 2014;9(6):e100283.

48. Kyto JP, Harjutsalo V, Forsblom C, Hietala K, Summanen PA, Groop PH. Decline in the cumulative incidence of severe diabetic retinopathy in patients with type 1 diabetes. Diabetes Care. 2011;34(9):2005-7.

49. Thomas RL, Dunstan F, Luzio SD, Roy Chowdury S, Hale SL, North RV, et al. Incidence of diabetic retinopathy in people with type 2 diabetes mellitus attending the diabetic retinopathy screening service for wales: retrospective analysis. BMJ. 2012;344:e874.

50. Younis N, Broadbent DM, Vora JP, Harding SP. Incidence of sightthreatening retinopathy in patients with type 2 diabetes in the Liverpool Diabetic Eye Study: a cohort study. Lancet. 2003;361(9353):195-200.

51. Stratton IM, Kohner EM, Aldington SJ, Turner RC, Holman RR, Manley SE, et al. UKPDS 50: risk factors for incidence and progression of retinopathy in Type II diabetes over 6 years from diagnosis. Diabetologia. 2001:44(2):156-63.

52. Jones CD, Greenwood RH, Misra A, Bachmann MO. Incidence and progression of diabetic retinopathy during 17 years of a population-based screening program in England. Diabetes Care. 2012;35(3):592-6.

53. Tudor SM, Hamman RF, Baron A, Johnson DW, Shetterly SM. Incidence and progression of diabetic retinopathy in Hispanics and non-Hispanic whites with type 2 diabetes. San Luis Valley Diabetes Study, Colorado. Diabetes Care. 1998;21(1):53-61.

54. Varma R, Choudhury F, Klein R, Chung J, Torres M, Azen SP. Four-year incidence and progression of diabetic retinopathy and macular edema: the Los Angeles Latino Eye Study. Am J Ophthalmol. 2010;149(5):752-61. e1-3. 
55. Lee ET, Lee VS, Kingsley RM, Lu M, Russell D, Asal NR, et al. Diabetic retinopathy in Oklahoma Indians with NIDDM. Incidence and risk factors. Diabetes Care. 1992;15(11):1620-7.

56. Cikamatana L, Mitchell P, Rochtchina E, Foran S, Wang JJ. Five-year incidence and progression of diabetic retinopathy in a defined older population: the Blue Mountains Eye Study. Eye (Lond). 2007;21(4):465-71.

57. Leske MC, Wu SY, Hennis A, Nemesure B, Schachat AP, Hyman L, et al. Nineyear incidence of diabetic retinopathy in the Barbados Eye Studies. Arch Ophthalmol. 2006;124(2):250-5.

58. Tapp RJ, Zimmet PZ, Harper CA, McCarty DJ, Chitson P, Tonkin AM, et al. Six year incidence and progression of diabetic retinopathy: results from the Mauritius diabetes complication study. Diabetes Res Clin Pract. 2006;73(3):298-303.

59. Salinero-Fort MA, San Andres-Rebollo FJ, de Burgos-Lunar C, Arrieta-Blanco FJ, Gomez-Campelo P. Four-year incidence of diabetic retinopathy in a Spanish cohort: the MADIABETES study. PLoS One. 2013;8(10):e76417.

60. Tam VH, Lam EP, Chu BC, Tse KK, Fung LM. Incidence and progression of diabetic retinopathy in Hong Kong Chinese with type 2 diabetes mellitus. J Diabetes Complications. 2009;23(3):185-93.

61. Song H, Liu L, Sum R, Fung M, Yap MK. Incidence of diabetic retinopathy in a Hong Kong Chinese population. Clin Exp Optom. 2011;94(6):563-7.

62. Kawasaki R, Tanaka S, Tanaka S, Yamamoto T, Sone H, Ohashi Y, et al. Incidence and progression of diabetic retinopathy in Japanese adults with type 2 diabetes: 8 year follow-up study of the Japan Diabetes Complications Study (JDCS). Diabetologia. 2011;54(9):2288-94.

63. Fundus photographic risk factors for progression of diabetic retinopathy. ETDRS report number 12. Early Treatment Diabetic Retinopathy Study Research Group. Ophthalmology. 1991;98(5 Suppl):823-33.

64. Al-Rubeaan K, Abu El-Asrar AM, Youssef AM, Subhani SN, Ahmad NA, AlSharqawi $\mathrm{AH}$, et al. Diabetic retinopathy and its risk factors in a society with a type 2 diabetes epidemic: a Saudi National Diabetes Registry-based study. Acta Ophthalmol. 2015;93(2):e140-7.

65. Pugliese G, Solini A, Zoppini G, Fondelli C, Zerbini G, Vedovato M, et al. High prevalence of advanced retinopathy in patients with type 2 diabetes from the Renal Insufficiency and Cardiovascular Events (RIACE) Italian Multicenter Study. Diabetes Res Clin Pract. 2012;98(2):329-37.

66. Dutra Medeiros M, Mesquita E, Papoila AL, Genro V, Raposo JF. First diabetic retinopathy prevalence study in Portugal: RETINODIAB Study-Evaluation of the screening programme for Lisbon and Tagus Valley region. $\mathrm{Br} J$ Ophthalmol. 2015 doi:10.1136/bjophthalmol-2015-306727 [Epub ahead of print].

67. Nathoo N, Ng M, Rudnisky CJ, Tennant MT. The prevalence of diabetic retinopathy as identified by teleophthalmology in rural Alberta. Can J Ophthalmol. 2010;45(1):28-32.

68. Esteves JF, Kramer CK, Azevedo MJ, Stolz AP, Roggia MF, Larangeira A, et al. Prevalence of diabetic retinopathy in patients with type 1 diabetes mellitus. Rev Assoc Med Bras. 2009;55(3):268-73.

69. Villena JE, Yoshiyama CA, Sanchez JE, Hilario NL, Merin LM. Prevalence of diabetic retinopathy in Peruvian patients with type 2 diabetes: results of a hospital-based retinal telescreening program. Rev Panam Salud Publica. 2011;30(5):408-14.

70. Thomas RL, Distiller L, Luzio SD, Chowdhury SR, Melville VJ, Kramer B, et al. Ethnic differences in the prevalence of diabetic retinopathy in persons with diabetes when first presenting at a diabetes clinic in South Africa. Diabetes Care. 2013;36(2):336-41.

71. Kaidonis G, Mills RA, Landers J, Lake SR, Burdon KP, Craig JE. Review of the prevalence of diabetic retinopathy in Indigenous Australians. Clin Experiment Ophthalmol. 2014;42(9):875-82.

72. Virgili G, Menchini F, Murro V, Peluso E, Rosa F, Casazza G. Optical coherence tomography $(\mathrm{OCT})$ for detection of macular oedema in patients with diabetic retinopathy. Cochrane Database Syst Rev. 2011;7:CD008081

73. Klein R, Knudtson MD, Lee KE, Gangnon R, Klein BE. The Wisconsin Epidemiologic Study of Diabetic Retinopathy XXIII: the twenty-five-year incidence of macular edema in persons with type 1 diabetes. Ophthalmology. 2009;116(3):497-503.

74. Ding J, Wong TY. Current epidemiology of diabetic retinopathy and diabetic macular edema. Curr Diab Rep. 2012;12(4):346-54.

75. Xu J, Xu L, Wang YX, You QS, Jonas JB, Wei WB. Ten-year cumulative incidence of diabetic retinopathy. The Beijing Eye Study 2001/2011. PLoS One. 2014;9(10):e111320.
76. Kajiwara A, Miyagawa H, Saruwatari J, Kita A, Sakata M, Kawata Y, et al. Gender differences in the incidence and progression of diabetic retinopathy among Japanese patients with type 2 diabetes mellitus: a clinic-based retrospective longitudinal study. Diabetes Res Clin Pract. 2014;103(3):e7-10.

77. Romero-Aroca P, Baget-Bernaldiz M, Fernandez-Ballart J, Plana-Gil N, SolerLluis N, Mendez-Marin I, et al. Ten-year incidence of diabetic retinopathy and macular edema. Risk factors in a sample of people with type 1 diabetes. Diabetes Res Clin Pract. 2011;94(1):126-32.

78. Olsen BS, Sjolie AK, Hougaard P, Johannesen J, Marinelli K, Jacobsen BB, et al. The significance of the prepubertal diabetes duration for the development of retinopathy and nephropathy in patients with type 1 diabetes. J Diabetes Complications. 2004;18(3):160-4.

79. Donaghue KC, Fairchild JM, Craig ME, Chan AK, Hing S, Cutler LR, et al. Do all prepubertal years of diabetes duration contribute equally to diabetes complications? Diabetes Care. 2003;26(4):1224-9.

80. Harjutsalo V, Maric C, Forsblom C, Thorn L, Waden J, Groop PH. Sex-related differences in the long-term risk of microvascular complications by age at onset of type 1 diabetes. Diabetologia. 2011;54(8):1992-9.

81. Chen S, Jim B, Ziyadeh FN. Diabetic nephropathy and transforming growth factor-beta: transforming our view of glomerulosclerosis and fibrosis buildup. Semin Nephrol. 2003;23(6):532-43.

82. Egan AM, McVicker L, Heerey A, Carmody L, Harney F, Dunne FP. Diabetic retinopathy in pregnancy: a population-based study of women with pregestational diabetes. J Diabetes Res. 2015;2015:310239. doi:10.1155/2015/310239.

83. Diabetes Control and Complications Trial Research Group. Effect of pregnancy on microvascular complications in the diabetes control and complications trial. The Diabetes Control and Complications Trial Research Group. Diabetes Care. 2000;23(8):1084-91.

84. Ringholm L, Vestgaard M, Laugesen CS, Juul A, Damm P, Mathiesen ER. Pregnancy-induced increase in circulating IGF-I is associated with progression of diabetic retinopathy in women with type 1 diabetes. Growth Horm IGF Res. 2011;21(1):25-30.

85. Kastelan S, Tomic M, Pavan J, Oreskovic S. Maternal immune system adaptation to pregnancy-a potential influence on the course of diabetic retinopathy. Reprod Biol Endocrinol. 2010;8:124.

86. Wong TY, Liew G, Tapp RJ, Schmidt MI, Wang JJ, Mitchell P, et al. Relation between fasting glucose and retinopathy for diagnosis of diabetes: three population-based cross-sectional studies. Lancet. 2008;371(9614):736-43.

87. Mohamed Q, Gillies MC, Wong TY. Management of diabetic retinopathy: a systematic review. JAMA. 2007;298(8):902-16.

88. The effect of intensive treatment of diabetes on the development and progression of long-term complications in insulin-dependent diabetes mellitus. The Diabetes Control and Complications Trial Research Group. N Engl J Med. 1993;329(14):977-86.

89. Retinopathy and nephropathy in patients with type 1 diabetes four years after a trial of intensive therapy. The Diabetes Control and Complications Trial/Epidemiology of Diabetes Interventions and Complications Research Group. N Engl J Med. 2000;342(6):381-9.

90. Early worsening of diabetic retinopathy in the Diabetes Control and Complications Trial. Arch Ophthalmol. 1998;116(7):874-86.

91. White NH, Sun W, Cleary PA, Danis RP, Davis MD, Hainsworth DP, et al. Prolonged effect of intensive therapy on the risk of retinopathy complications in patients with type 1 diabetes mellitus: 10 years after the Diabetes Control and Complications Trial. Arch Ophthalmol. 2008;126(12):1707-15.

92. Lachin JM, White NH, Hainsworth DP, Sun W, Cleary PA, Nathan DM. Effect of intensive diabetes therapy on the progression of diabetic retinopathy in patients with type 1 diabetes: 18 years of follow-up in the DCCT/EDIC. Diabetes. 2015;64(2):631-42.

93. Hirose A, Furushima D, Yamaguchi N, Kitano S, Uchigata Y. Prediction of retinopathy at 20 years after onset in younger-onset type 1 diabetes using mean metabolic memory-free $\mathrm{HbA1c}$ values: the importance of using $\mathrm{HbA1c}$ data of total, not partial, diabetes duration. Diabetes Care. 2013;36(11):3812-4.

94. Smith-Palmer J, Brandle M, Trevisan R, Orsini Federici M, Liabat S, Valentine W. Assessment of the association between glycemic variability and diabetes-related complications in type 1 and type 2 diabetes. Diabetes Res Clin Pract. 2014;105(3):273-84. 
95. Patel A, MacMahon S, Chalmers J, Neal B, Billot L, Woodward M, et al. Intensive blood glucose control and vascular outcomes in patients with type 2 diabetes. N Engl J Med. 2008;358(24):2560-72.

96. Gerstein HC, Miller ME, Byington RP, Goff Jr DC, Bigger JT, Buse JB, et al. Effects of intensive glucose lowering in type 2 diabetes. $N$ Engl J Med. 2008;358(24):2545-59.

97. Fullerton B, Jeitler K, Seitz M, Horvath K, Berghold A, Siebenhofer A. Intensive glucose control versus conventional glucose control for type 1 diabetes mellitus. Cochrane Database Syst Rev. 2014;2:CD009122.

98. Jin P, Peng J, Zou H, Wang W, Fu J, Shen B, et al. The 5-year onset and regression of diabetic retinopathy in Chinese type 2 diabetes patients. PLoS One. 2014;9(11):e113359.

99. Tight blood pressure control and risk of macrovascular and microvascular complications in type 2 diabetes: UKPDS 38. UK Prospective Diabetes Study Group. BMJ. 1998;317(7160):703-13.

100. Holman RR, Paul SK, Bethel MA, Neil HA, Matthews DR. Long-term follow-up after tight control of blood pressure in type 2 diabetes. N Engl J Med. 2008;359(15):1565-76.

101. Chaturvedi N, Porta M, Klein R, Orchard T, Fuller J, Parving HH, et al. Effect of candesartan on prevention (DIRECT-Prevent 1) and progression (DIRECTProtect 1) of retinopathy in type 1 diabetes: randomised, placebo-controlled trials. Lancet. 2008;372(9647):1394-402.

102. Sjolie AK, Klein R, Porta M, Orchard T, Fuller J, Parving HH, et al. Effect of candesartan on progression and regression of retinopathy in type 2 diabetes (DIRECT-Protect 2): a randomised placebo-controlled trial. Lancet. 2008;372(9647):1385-93.

103. Do DV, Wang X, Vedula SS, Marrone M, Sleilati G, Hawkins BS, et al. Blood pressure control for diabetic retinopathy. Cochrane Database Syst Rev. 2015;1:CD006127.

104. Preiss D, Seshasai SR, Welsh P, Murphy SA, Ho JE, Waters DD, et al. Risk of incident diabetes with intensive-dose compared with moderate-dose statin therapy: a meta-analysis. JAMA. 2011;305(24):2556-64

105. Sheely D, Jialal I. Strategies to lower low-density lipoprotein cholesterol in metabolic syndrome: averting the diabetes risk. Metab Syndr Relat Disord. 2013;11(3):149-51.

106. Keech AC, Mitchell P, Summanen PA, O'Day J, Davis TM, Moffitt MS, et al. Effect of fenofibrate on the need for laser treatment for diabetic retinopathy (FIELD study): a randomised controlled trial. Lancet. 2007;370(9600):1687-97.

107. Chew EY, Ambrosius WT, Davis MD, Danis RP, Gangaputra S, Greven CM, et al. Effects of medical therapies on retinopathy progression in type 2 diabetes. $\mathrm{N}$ Engl J Med. 2010;363(3):233-44.

108. Massin P, Peto T, Ansquer JC, Aubonnet P, Macu FENSIFT. Effects of fenofibric acid on diabetic macular edema: the MacuFen study. Ophthalmic Epidemiol. 2014;21(5):307-17.

109. Elam M, Lovato LC, Ginsberg H. Role of fibrates in cardiovascular disease prevention, the ACCORD-Lipid perspective. Curr Opin Lipidol. 2011;22(1):55-61

110. Cheung N, Wong TY. Obesity and eye diseases. Surv Ophthalmol. 2007:52(2):180-95.

111. Henricsson M, Nystrom L, Blohme G, Ostman J, Kullberg C, Svensson M, et al. The incidence of retinopathy 10 years after diagnosis in young adult people with diabetes: results from the nationwide population-based Diabetes Incidence Study in Sweden (DISS). Diabetes Care. 2003;26(2):349-54

112. Chaturvedi N, Sjoelie AK, Porta M, Aldington SJ, Fuller JH, Songini M, et al. Markers of insulin resistance are strong risk factors for retinopathy incidence in type 1 diabetes. Diabetes Care. 2001;24(2):284-9.

113. Lu J, Hou X, Zhang L, Jiang F, Hu C, Bao Y, et al. Association between body mass index and diabetic retinopathy in Chinese patients with type 2 diabetes. Acta Diabetol. 2015;52(4):701-8.

114. Rooney D, Lye WK, Tan G, Lamoureux EL, Ikram MK, Cheng CY, et al. Body mass index and retinopathy in Asian populations with diabetes mellitus. Acta Diabetol. 2015;52(1):73-80

115. Rudrappa S, Warren G, Idris I. Obstructive sleep apnoea is associated with the development and progression of diabetic retinopathy, independent of conventional risk factors and novel biomarkers for diabetic retinopathy. $\mathrm{Br}$ J Ophthalmol. 2012;96(12):1535.

116. Mason RH, West SD, Kiire CA, Groves DC, Lipinski HJ, Jaycock A, et al. High prevalence of sleep disordered breathing in patients with diabetic macular edema. Retina. 2012;32(9):1791-8.
117. Cheung D, Switzer NJ, Ehmann D, Rudnisky C, Shi X, Karmali S. The impact of bariatric surgery on diabetic retinopathy: a systematic review and metaanalysis. Obes Surg. 2015;25(9):1604-9.

118. Tang J, Kern TS. Inflammation in diabetic retinopathy. Prog Retin Eye Res. 2011;30(5):343-58.

119. Schram MT, Chaturvedi N, Schalkwijk CG, Fuller JH, Stehouwer CD. Markers of inflammation are cross-sectionally associated with microvascular complications and cardiovascular disease in type 1 diabetes-the EURODIAB Prospective Complications Study. Diabetologia. 2005;48(2):370-8.

120. Nguyen TT, Alibrahim E, Islam FM, Klein R, Klein BE, Cotch MF, et al. Inflammatory, hemostatic, and other novel biomarkers for diabetic retinopathy: the multi-ethnic study of atherosclerosis. Diabetes Care. 2009;32(9):1704-9.

121. Lim LS, Tai ES, Mitchell P, Wang JJ, Tay WT, Lamoureux E, et al. C-reactive protein, body mass index, and diabetic retinopathy. Invest Ophthalmol Vis Sci. 2010;51(9):4458-63.

122. A randomized trial comparing intravitreal triamcinolone acetonide and focal/grid photocoagulation for diabetic macular edema. Ophthalmology. 2008;115(9):1447-9, 1149.e1-10. doi:10.1016/j.ophtha.2008.06.015.

123. Beck RW, Edwards AR, Aiello LP, Bressler NM, Ferris F, Glassman AR, et al. Three-year follow-up of a randomized trial comparing focal/grid photocoagulation and intravitreal triamcinolone for diabetic macular edema. Arch Ophthalmol. 2009;127(3):245-51.

124. Angelo LS, Kurzrock R. Vascular endothelial growth factor and its relationship to inflammatory mediators. Clin Cancer Res. 2007;13(10):2825-30.

125. Jardeleza MS, Miller JW. Review of anti-VEGF therapy in proliferative diabetic retinopathy. Semin Ophthalmol. 2009;24(2):87-92.

126. Colucciello M. Current intravitreal pharmacologic therapies for diabetic macular edema. Postgrad Med. 2015;127(6):640-53.

127. Mitchell P, Bandello F, Schmidt-Erfurth U, Lang GE, Massin P, Schlingemann $\mathrm{RO}$, et al. The RESTORE study: ranibizumab monotherapy or combined with laser versus laser monotherapy for diabetic macular edema. Ophthalmology. 2011;118(4):615-25.

128. Bressler SB, Almukhtar T, Bhorade A, Bressler NM, Glassman AR, Huang SS, et al. Repeated intravitreous ranibizumab injections for diabetic macular edema and the risk of sustained elevation of intraocular pressure or the need for ocular hypotensive treatment. JAMA Ophthalmol.

2015;133(5):589-97.

129. Wells JA, Glassman AR, Ayala AR, Jampol LM, Aiello LP, Antoszyk AN, et al. Aflibercept, bevacizumab, or ranibizumab for diabetic macular edema. N Engl J Med. 2015;372(13):1193-203.

130. Elman MJ, Aiello LP, Beck RW, Bressler NM, Bressler SB, Edwards AR, et al. Randomized trial evaluating ranibizumab plus prompt or deferred laser or triamcinolone plus prompt laser for diabetic macular edema. Ophthalmology. 2010;117(6):1064-77. e35.

131. Elman MJ, Bressler NM, Qin H, Beck RW, Ferris 3rd FL, Friedman SM, et al. Expanded 2-year follow-up of ranibizumab plus prompt or deferred laser or triamcinolone plus prompt laser for diabetic macular edema. Ophthalmology. 2011;118(4):609-14.

132. Wozniak SE, Gee LL, Wachtel MS, Frezza EE. Adipose tissue: the new endocrine organ? A review article. Dig Dis Sci. 2009;54(9):1847-56.

133. Yamagishi S, Inagaki Y, Amano S, Okamoto T, Takeuchi M. Up-regulation of vascular endothelial growth factor and down-regulation of pigment epithelium-derived factor messenger ribonucleic acid levels in leptin-exposed cultured retinal pericytes. Int J Tissue React. 2002;24(4):137-42.

134. Suganami E, Takagi H, Ohashi H, Suzuma K, Suzuma I, Oh H, et al. Leptin stimulates ischemia-induced retinal neovascularization: possible role of vascular endothelial growth factor expressed in retinal endothelial cells. Diabetes. 2004;53(9):2443-8.

135. Gariano RF, Nath AK, D'Amico DJ, Lee T, Sierra-Honigmann MR. Elevation of vitreous leptin in diabetic retinopathy and retinal detachment. Invest Ophthalmol Vis Sci. 2000:41(11):3576-81.

136. Dossarps D, Petit JM, Guiu B, Cercueil JP, Duvillard L, Bron AM, et al. Body fat distribution and adipokine secretion are not associated with diabetic retinopathy in patients with type 2 diabetes mellitus. Ophthalmic Res. 2014;51(1):42-5.

137. Sari R, Balci MK, Apaydin C. The relationship between plasma leptin levels and chronic complication in patients with type 2 diabetes mellitus. Metab Syndr Relat Disord. 2010;8(6):499-503. 
138. Omae T, Nagaoka T, Tanano I, Yoshida A. Adiponectin-induced dilation of isolated porcine retinal arterioles via production of nitric oxide from endothelial cells. Invest Ophthalmol Vis Sci. 2013;54(7):4586-94.

139. Omae T, Nagaoka T, Yoshida A. Relationship between retinal blood flow and serum adiponectin concentrations in patients with type 2 diabetes mellitus. Invest Ophthalmol Vis Sci. 2015:56(6):4143-9.

140. Srinivasan V, Sulochana KN. Effect of adiponectin on expression of vascular endothelial growth factor and pigment epithelium-derived factor: an in vitro study. Indian J Pharmacol. 2015;47(1):117-20.

141. Pradeepa R, Surendar J, Indulekha K, Chella S, Anjana RM, Mohan V. Association of serum adiponectin with diabetic microvascular complications among south Indian type 2 diabetic subjects - (CURES-133). Clin Biochem. 2015:48(1-2):33-8.

142. Zietz B, Buechler C, Kobuch K, Neumeier M, Scholmerich J, Schaffler A. Serum levels of adiponectin are associated with diabetic retinopathy and with adiponectin gene mutations in Caucasian patients with diabetes mellitus type 2. Exp Clin Endocrinol Diabetes. 2008;116(9):532-6.

143. Yilmaz MI, Sonmez A, Acikel C, Celik T, Bingol N, Pinar M, et al. Adiponectin may play a part in the pathogenesis of diabetic retinopathy. Eur J Endocrinol. 2004;151(1):135-40.

144. Madsen-Bouterse SA, Kowluru RA. Oxidative stress and diabetic retinopathy: pathophysiological mechanisms and treatment perspectives. Rev Endocr Metab Disord. 2008;9(4):315-27.

145. Robison Jr WG, Jacot JL, Katz ML, Glover JP. Retinal vascular changes induced by the oxidative stress of alpha-tocopherol deficiency contrasted with diabetic microangiopathy. J Ocul Pharmacol Ther. 2000;16(2):109-20.

146. Kowluru RA. Diabetic retinopathy: mitochondrial dysfunction and retinal capillary cell death. Antioxid Redox Signal. 2005;7(11-12):1581-87.

147. Naruse R, Suetsugu M, Terasawa T, Ito K, Hara K, Takebayashi K, et al. Oxidative stress and antioxidative potency are closely associated with diabetic retinopathy and nephropathy in patients with type 2 diabetes. Saudi Med J. 2013;34(2):135-41.

148. Wu Y, Tang L, Chen B. Oxidative stress: implications for the development of diabetic retinopathy and antioxidant therapeutic perspectives. Oxid Med Cell Longev. 2014;2014:752387.

149. Yamagishi S, Matsui T. Advanced glycation end products (AGEs), oxidative stress and diabetic retinopathy. Curr Pharm Biotechnol. 2011;12(3):362-8.

150. Oates PJ, Mylari BL. Aldose reductase inhibitors: therapeutic implications for diabetic complications. Expert Opin Investig Drugs. 1999;8(12):2095-119.

151. PKC-DRS Study Group. The effect of ruboxistaurin on visual loss in patients with moderately severe to very severe nonproliferative diabetic retinopathy: initial results of the Protein Kinase C beta Inhibitor Diabetic Retinopathy Study (PKC-DRS) multicenter randomized clinical trial. Diabetes. 2005;54(7):2188-97.

152. Aiello LP, Davis MD, Girach A, Kles KA, Milton RC, Sheetz MJ, et al. Effect of ruboxistaurin on visual loss in patients with diabetic retinopathy. Ophthalmology. 2006;113(12):2221-30.

153. Bolton WK, Cattran DC, Williams ME, Adler SG, Appel GB, Cartwright K, et al. Randomized trial of an inhibitor of formation of advanced glycation end products in diabetic nephropathy. Am J Nephrol. 2004;24(1):32-40.

154. Brzovic-Saric V, Landeka I, Saric B, Barberic M, Andrijasevic L, Cerovski B, et al. Levels of selected oxidative stress markers in the vitreous and serum of diabetic retinopathy patients. Mol Vis. 2015;21:649-64.

155. Pan HZ, Zhang H, Chang D, Li H, Sui $H$. The change of oxidative stress products in diabetes mellitus and diabetic retinopathy. Br J Ophthalmol. 2008;92(4):548-51.

156. Pludowski P, Holick MF, Pilz S, Wagner CL, Hollis BW, Grant WB, et al. Vitamin D effects on musculoskeletal health, immunity, autoimmunity, cardiovascular disease, cancer, fertility, pregnancy, dementia and mortality-a review of recent evidence. Autoimmun Rev. 2013;12(10):976-89.

157. Albert DM, Scheef EA, Wang S, Mehraein F, Darjatmoko SR, Sorenson CM, et al. Calcitriol is a potent inhibitor of retinal neovascularization. Invest Ophthalmol Vis Sci. 2007:48(5):2327-34.

158. Ren Z, Li W, Zhao Q, Ma L, Zhu J. The impact of 1,25-dihydroxy vitamin D3 on the expressions of vascular endothelial growth factor and transforming growth factor-beta(1) in the retinas of rats with diabetes. Diabetes Res Clin Pract. 2012;98(3):474-80.

159. Kaur H, Donaghue KC, Chan AK, Benitez-Aguirre P, Hing S, Lloyd M, et al. Vitamin $D$ deficiency is associated with retinopathy in children and adolescents with type 1 diabetes. Diabetes Care. 2011;34(6):1400-2.
160. Shimo N, Yasuda T, Kaneto H, Katakami N, Kuroda A, Sakamoto F, et al. Vitamin $\mathrm{D}$ deficiency is significantly associated with retinopathy in young Japanese type 1 diabetic patients. Diabetes Res Clin Pract. 2014;106(2):e41-3.

161. He R, Shen J, Liu F, Zeng H, Li L, Yu H, et al. Vitamin D deficiency increases the risk of retinopathy in Chinese patients with type 2 diabetes. Diabet Med. 2014;31(12):1657-64.

162. Jee D, Han K, Kim EC. Inverse association between high blood 25hydroxyvitamin $\mathrm{D}$ levels and diabetic retinopathy in a representative Korean population. PLoS One. 2014;9(12):e115199.

163. Alcubierre N, Valls J, Rubinat E, Cao G, Esquerda A, Traveset A, et al. Vitamin $D$ deficiency is associated with the presence and severity of diabetic retinopathy in type 2 diabetes mellitus. J Diabetes Res. 2015;2015:374178.

164. Patel S, Chen H, Tinkham NH, Zhang K. Genetic susceptibility of diabetic retinopathy. Curr Diab Rep. 2008;8(4):257-62

165. Hallman DM, Huber Jr JC, Gonzalez VH, Klein BE, Klein R, Hanis CL. Familial aggregation of severity of diabetic retinopathy in Mexican Americans from Starr County, Texas. Diabetes Care. 2005;28(5):1163-8.

166. Hietala K, Forsblom C, Summanen P, Groop PH. Heritability of proliferative diabetic retinopathy. Diabetes. 2008:57(8):2176-80.

167. Arar NH, Freedman BI, Adler SG, lyengar SK, Chew EY, Davis MD, et al. Heritability of the severity of diabetic retinopathy: the FIND-Eye study. Invest Ophthalmol Vis Sci. 2008:49(9):3839-45.

168. Clustering of long-term complications in families with diabetes in the diabetes control and complications trial. The Diabetes Control and Complications Trial Research Group. Diabetes. 1997;46(11):1829-39.

169. Wang H, Cheng JW, Zhu LS, Wei RL, Cai JP, Li Y, et al. Meta-analysis of association between the -2578C/A polymorphism of the vascular endothelial growth factor and retinopathy in type 2 diabetes in Asians and Caucasians. Ophthalmic Res. 2014;52(1):1-8.

170. Han L, Zhang L, Xing W, Zhuo R, Lin X, Hao Y, et al. The associations between VEGF gene polymorphisms and diabetic retinopathy susceptibility: a meta-analysis of 11 case-control studies. J Diabetes Res. 2014;2014:805801.

171. El-Shazly SF, El-Bradey MH, Tameesh MK. Vascular endothelial growth factor gene polymorphism prevalence in patients with diabetic macular oedema and its correlation with anti-vascular endothelial growth factor treatment outcomes. Clin Experiment Ophthalmol. 2014;42(4):369-78.

172. Kaidonis G, Burdon KP, Gillies MC, Abhary S, Essex RW, Chang JH, et al. Common Sequence Variation in the VEGFC Gene Is Associated with Diabetic Retinopathy and Diabetic Macular Edema. Ophthalmology. 2015. doi:10.1016/j.ophtha.2015.05.004.

173. Zhou M, Zhang $P$, Xu X, Sun $X$. The relationship between aldose reductase C106T polymorphism and diabetic retinopathy: an updated meta-analysis. Invest Ophthalmol Vis Sci. 2015;56(4):2279-89.

174. El-Bab MF, Zaki NS, Mojaddidi MA, Al-Barry M, El-Beshbishy HA. Diabetic retinopathy is associated with oxidative stress and mitigation of gene expression of antioxidant enzymes. Int J Gen Med. 2013;6:799-806.

175. Taverna MJ, Sola A, Guyot-Argenton C, Pacher N, Bruzzo F, Slama G, et al. Taq I polymorphism of the vitamin D receptor and risk of severe diabetic retinopathy. Diabetologia. 2002;45(3):436-42.

176. Taverna MJ, Selam JL, Slama G. Association between a protein polymorphism in the start codon of the vitamin D receptor gene and severe diabetic retinopathy in C-peptide-negative type 1 diabetes. J Clin Endocrinol Metab. 2005;90(8):4803-8.

177. Grassi MA, Tikhomirov A, Ramalingam S, Below JE, Cox NJ, Nicolae DL. Genome-wide meta-analysis for severe diabetic retinopathy. Hum Mol Genet. 2011;20(12):2472-81.

178. Huang YC, Lin JM, Lin HJ, Chen CC, Chen SY, Tsai CH, et al. Genome-wide association study of diabetic retinopathy in a Taiwanese population. Ophthalmology. 2011;118(4):642-8.

179. Sheu WH, Kuo JZ, Lee IT, Hung YJ, Lee WJ, Tsai HY, et al. Genome-wide association study in a Chinese population with diabetic retinopathy. Hum Mol Genet. 2013;22(15):3165-73.

180. Awata T, Yamashita H, Kurihara S, Morita-Ohkubo T, Miyashita Y, Katayama S, et al. A genome-wide association study for diabetic retinopathy in a Japanese population: potential association with a long intergenic noncoding RNA. PLoS One. 2014;9(11):e111715.

181. Wang WJ, Tay HG, Soni R, Perumal GS, Goll MG, Macaluso FP, et al. CEP162 is an axoneme-recognition protein promoting ciliary transition zone assembly at the cilia base. Nat Cell Biol. 2013;15(6):591-601. 
182. Bourne RR, Jonas JB, Flaxman SR, Keeffe J, Leasher J, Naidoo K, et al. Prevalence and causes of vision loss in high-income countries and in Eastern and Central Europe: 1990-2010. Br J Ophthalmol. 2014;98(5):629-38.

183. Keeffe J, Taylor HR, Fotis K, Pesudovs K, Flaxman SR, Jonas JB, et al, Prevalence and causes of vision loss in Southeast Asia and Oceania: 1990-2010. Br J Ophthalmol. 2014;98(5):586-91.

184. Naidoo K, Gichuhi S, Basanez MG, Flaxman SR, Jonas JB, Keeffe J, et al. Prevalence and causes of vision loss in sub-Saharan Africa: 1990-2010. Br J Ophthalmol. 2014;98(5):612-8.

185. Klein R, Lee KE, Gangnon RE, Klein BE. The 25-year incidence of visual impairment in type 1 diabetes mellitus the wisconsin epidemiologic study of diabetic retinopathy. Ophthalmology. 2010;117(1):63-70.

186. Arora S, Kolb S, Goyder E, McKibbin M. Trends in the incidence of visual impairment certification secondary to diabetic retinopathy in the Leeds metropolitan area, 2005-2010. Diabet Med. 2012;29(7):e112-6.

187. Hall HN, Chinn DJ, Sinclair A, Styles CJ. Epidemiology of blindness attributable to diabetes in Scotland: change over 20 years in a defined population. Diabet Med. 2013;30(11):1349-54.

188. Rani PK, Raman R, Gella L, Kulothungan V, Sharma T. Prevalence of visual impairment and associated risk factors in subjects with type II diabetes mellitus: sankara nethralaya diabetic retinopathy epidemiology and molecular genetics study (SN-DREAMS, report 16). Middle East Afr J Ophthalmol. 2012;19(1):129-34.

189. Chiang PP, Lamoureux EL, Zheng Y, Tay WT, Mitchell P, Wang JJ, et al. Frequency and risk factors of non-retinopathy ocular conditions in people with diabetes: the Singapore Malay Eye Study. Diabet Med. 2013:30(2):e32-40

190. Klein BE, Klein R, Moss SE. Incidence of cataract surgery in the Wisconsin Epidemiologic Study of Diabetic Retinopathy. Am J Ophthalmol. 1995;119(3):295-300.

191. Baker CW, Almukhtar T, Bressler NM, Glassman AR, Grover S, Kim SJ, et al. Macular edema after cataract surgery in eyes without preoperative central-involved diabetic macular edema. JAMA Ophthalmol. 2013;131(7):870-9.

192. Jeganathan VS, Wang JJ, Wong TY. Ocular associations of diabetes other than diabetic retinopathy. Diabetes Care. 2008;31(9):1905-12.

193. Goto A, Inatani M, Inoue T, Awai-Kasaoka N, Takihara Y, Ito Y, et al. Frequency and risk factors for neovascular glaucoma after vitrectomy in eyes with proliferative diabetic retinopathy. J Glaucoma. 2013;22(7):572-6.

194. Lee WJ, Sobrin L, Lee MJ, Kang MH, Seong M, Cho H. The relationship between diabetic retinopathy and diabetic nephropathy in a populationbased study in Korea (KNHANES V-2, 3). Invest Ophthalmol Vis Sci. 2014:55(10):6547-53.

195. Lee WJ, Sobrin L, Kang MH, Seong M, Kim YJ, Yi JH, et al. Ischemic diabetic retinopathy as a possible prognostic factor for chronic kidney disease progression. Eye (Lond). 2014;28(9):1119-25.

196. Grunwald JE, Alexander J, Ying GS, Maguire M, Daniel E, Whittock-Martin R, et al. Retinopathy and chronic kidney disease in the Chronic Renal Insufficiency Cohort (CRIC) study. Arch Ophthalmol. 2012;130(9):1136-44.

197. Romero P, Baget M, Mendez I, Fernandez J, Salvat M, Martinez I. Diabetic macular edema and its relationship to renal microangiopathy: a sample of Type I diabetes mellitus patients in a 15-year follow-up study. J Diabetes Complications. 2007;21(3):172-80.

198. Pradeepa R, Surendar J, Indulekha K, Chella S, Anjana RM, Mohan V. Relationship of diabetic retinopathy with coronary artery disease in Asian Indians with type 2 diabetes: the Chennai Urban Rural Epidemiology Study (CURES) Eye Study-3. Diabetes Technol Ther. 2015;17(2):112-8.

199. Cosson E, Nguyen MT, Chanu B, Balta S, Takbou K, Valensi P. The report of male gender and retinopathy status improves the current consensus guidelines for the screening of myocardial ischemia in asymptomatic type 2 diabetic patients. Nutr Metab Cardiovasc Dis. 2013;23(6):557-65.

200. Ricardo AC, Grunwald JE, Parvathaneni S, Goodin S, Ching A, Lash JP. Retinopathy and CKD as predictors of all-cause and cardiovascular mortality: National Health and Nutrition Examination Survey (NHANES) 1988-1994. Am J Kidney Dis. 2014;64(2):198-203.

201. Chen YW, Wang YY, Zhao D, Yu CG, Xin Z, Cao X, et al. High prevalence of lower extremity peripheral artery disease in type 2 diabetes patients with proliferative diabetic retinopathy. PLoS One. 2015;10(3):e0122022.

202. Abougalambou SS, Abougalambou AS. Risk factors associated with diabetic retinopathy among type 2 diabetes patients at teaching hospital in Malaysia. Diabetes Metab Syndr. 2015;9(2):98-103.
203. Chiang PP, Lamoureux EL, Cheung CY, Sabanayagam C, Wong W, Tai ES, et al. Racial differences in the prevalence of diabetes but not diabetic retinopathy in a multi-ethnic Asian population. Invest Ophthalmol Vis Sci. 2011;52(10):7586-92.

204. Zheng Y, Lamoureux EL, Chiang PC, Anuar AR, Ding J, Wang JJ, et al. Language barrier and its relationship to diabetes and diabetic retinopathy. BMC Public Health. 2012;12:781.

205. Katulanda P, Ranasinghe P, Jayawardena R. Prevalence of retinopathy among adults with self-reported diabetes mellitus: the Sri Lanka diabetes and Cardiovascular Study. BMC Ophthalmol. 2014;14:100.

206. Schellini SA, Carvalho GM, Rendeiro FS, Padovani CR, Hirai FE. Prevalence of diabetes and diabetic retinopathy in a Brazilian population. Ophthalmic Epidemiol. 2014;21(1):33-8.

207. Papali'i-Curtin AT, Dalziel DM. Prevalence of diabetic retinopathy and maculopathy in Northland, New Zealand: 2011-2012. N Z Med J. 2013;126(1383):20-8.

208. Win Tin ST, Kenilorea G, Gadabu E, Tasserei J, Colagiuri R. The prevalence of diabetes complications and associated risk factors in Pacific Islands countries. Diabetes Res Clin Pract. 2014;103(1):114-8.

209. Tsugawa Y, Takahashi O, Meigs JB, Davis RB, Imamura F, Fukui T, et al. New diabetes diagnostic threshold of hemoglobin $A(1 \mathrm{C})$ and the 3-year incidence of retinopathy. Diabetes. 2012;61(12):3280-4.

210. Ahmed KR, Karim MN, Bhowmik B, Habib SH, Bukht MS, Ali L, et al. Incidence of diabetic retinopathy in Bangladesh: a 15-year follow-up study. J Diabetes. 2012:4(4):386-91.

211. Manaviat MR, Rashidi M, Afkhami-Ardekani M. Four years incidence of diabetic retinopathy and effective factors on its progression in type II diabetes. Eur J Ophthalmol. 2008;18(4):572-7.

212. Janghorbani $M$, Amini $M$, Ghanbari $H$, Safaiee $H$. Incidence of and risk factors for diabetic retinopathy in Isfahan, Iran. Ophthalmic Epidemiol. 2003;10(2):81-95.

213. Perol J, Balkau B, Guillausseau PJ, Massin P. A study of the 3-year incidence of diabetic retinopathy in a French diabetic population seen at Lariboisiere Hospital, Paris. Diabetes Metab. 2012;38(3):225-9.

214. Xie XW, Xu L, Wang YX, Jonas JB. Prevalence and associated factors of diabetic retinopathy. The Beijing Eye Study 2006. Graefes Arch Clin Exp Ophthalmol. 2008;246(11):1519-26.

215. Varma R, Bressler NM, Doan QV, Gleeson M, Danese M, Bower JK, et al. Prevalence of and risk factors for diabetic macular edema in the United States. JAMA Ophthalmol. 2014;132(11):1334-40.

216. Petrella RJ, Blouin J, Davies B, Barbeau M. Prevalence, demographics, and treatment characteristics of visual impairment due to diabetic macular edema in a representative Canadian cohort. J Ophthalmol. 2012;2012:159167.

\section{Submit your next manuscript to BioMed Central and take full advantage of:}

- Convenient online submission

- Thorough peer review

- No space constraints or color figure charges

- Immediate publication on acceptance

- Inclusion in PubMed, CAS, Scopus and Google Scholar

- Research which is freely available for redistribution 